\title{
Recent Applications of Pd-Catalyzed Suzuki-Miyaura and Buchwald-Hartwig Couplings in Pharmaceutical Process Chemistry
}

\author{
Balaram S. Takale ${ }^{1, * \mathbb{D}}$, Fan-Yi Kong ${ }^{2}$ and Ruchita R. Thakore ${ }^{1}$ \\ 1 Department of Chemistry and Biochemistry, University of California, Santa Barbara, CA 93106, USA; \\ rthakore@ucsb.edu \\ 2 Department of Chemistry, Pomona College, Claremont, CA 91711, USA; fkab2020@mymail.pomona.edu \\ * Correspondence: balaram_takale@ucsb.edu
}

check for updates

Citation: Takale, B.S.; Kong, F.-Y.; Thakore, R.R. Recent Applications of Pd-Catalyzed Suzuki-Miyaura and Buchwald-Hartwig Couplings in Pharmaceutical Process Chemistry. Organics 2022, 3, 1-21. https:// doi.org/10.3390/org3010001

Academic Editor: Takahiro Suzuki

Received: 1 November 2021

Accepted: 23 December 2021

Published: 18 January 2022

Publisher's Note: MDPI stays neutral with regard to jurisdictional claims in published maps and institutional affiliations.

Copyright: (C) 2022 by the authors. Licensee MDPI, Basel, Switzerland. This article is an open access article distributed under the terms and conditions of the Creative Commons Attribution (CC BY) license (https:// creativecommons.org/licenses/by/ $4.0 /)$.

\begin{abstract}
Cross-coupling reactions have changed the way complex molecules are synthesized. In particular, Suzuki-Miyaura and Buchwald-Hartwig amination reactions have given opportunities to elegantly make pharmaceutical ingredients. Indeed, these reactions are at the forefront of both the stages of drug development, medicinal chemistry, and process chemistry. On the one hand, these reactions have given medicinal chemists a resource to derivatize the core compound to arrive at scaffold rapidly. On the other hand, these cross couplings have offered the process chemists a smart tool to synthesize the development candidates safely, quickly, and efficiently. Generally, the application of cross-coupling reactions is broad. This review will specifically focus on their real (pharma) world applications in large-scale synthesis appearing in the last three years.
\end{abstract}

Keywords: catalysis; Suzuki-Miyaura; Buchwald-Hartwig amination; palladium; pharmaceuticals; process chemistry

\section{Introduction}

Metal catalyzed cross couplings have played a crucial role in different stages of drug development. For example, the drug discovery stage requires multiple compounds to be tested for the best biological activity, wherein rapid access to the chemical matter is very important. The ability of cross-coupling reactions to quickly derivatize the core compound results in the multiple compounds available for biological studies. The aim at this stage remains to get the compound in milligrams scale. This scenario changes rapidly as the compound moves to the next stage of development, where only a few out of many compounds are selected for toxicology and animal studies. The required amount of compound then increases to $10-100 \mathrm{~g}$, and most of the time, the chemistry used to make the compound in milligram scale will be replicated in this case. Once the compound enters the development phase, several factors need to be considered. At this stage, "how" instead of "what" is important-how to make the compounds efficiently, quickly, and safely with the best quality is given prime importance. Nevertheless, process chemists were quite hesitant to use Pd-catalyzed reactions given the high toxicity of residual Pd content in the final drug substance. According to Food Drug Administration (FDA), $\leq 10$ ppm Pd is allowed per dose [1,2]. This suggests that the old practice of cross-coupling reactions done using 5-10 mol\% (50,000-100,000 ppm) Pd catalyst would most probably lead to very high residual Pd. Hence, a tedious and costly downstream Pd cleaning process would be required. The recent advances both in the actual development of efficient Pd catalysts $[3,4]$ and $\mathrm{Pd}$ scavenging processes [5] have mostly solved this issue. How these two pathbreaking coupling reactions, Suzuki-Miyaura and Buchwald-Hartwig, are becoming the essence of drug development is discussed in this review. The detailed structure of ligands and catalysts used in the work described in this review is also given in Figure 1. 
<smiles>CC(C)c1cc(C(C)C)c(-c2ccccc2P(C2CCCCC2)C2CCCCC2)c(C(C)C)c1</smiles><smiles>CC1(C)c2cccc(P(c3ccccc3)c3ccccc3)c2Oc2c(P(c3ccccc3)c3ccccc3)cccc21</smiles>

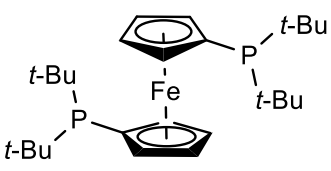

dppf<smiles>c1ccc(P(c2ccccc2)c2ccccc2Oc2ccccc2P(c2ccccc2)c2ccccc2)cc1</smiles>

DPEPhos<smiles>Cl[TeH]1Nc2ccccc2-c2ccccc21</smiles>

XantPhos-Pd-G2<smiles>CC(C)C[PH](c1ccccc1-c1c(C(C)C)cc(C(C)C)cc1C(C)C)(C(C)(C)C)P1(Cl)(Cl)NCCc2ccccc21</smiles>

$t$-BuXPhos-Pd-G1

JohnPhos

Figure 1. Structures of ligand and catalysts used in this review.

\section{Suzuki-Miyaura Coupling}

The Suzuki-Miyaura coupling remains a matured technology widely used in industrial synthesis. Although the initial discovery happened in 1979, the coupling's real applicability was realized most recently, owing to the discovery of new metal catalysts and bulky ligands that could couple complex starting materials. This success led to the Nobel prize in 2010 [6]. This reaction is so fundamentally and mechanistically well understood that it is possible to forge any complex $\mathrm{C}-\mathrm{C}$ bond from the respective aryl halide and aryl boron reagents. The Suzuki-Miyaura coupling is one of the widely used reactions in pharmaceutical synthesis. For example, St-Jean and coworkers [7] from Genentech developed an efficient late-stage synthetic method for PI3K $\beta$-Sparing Inhibitor taselisib 6 [8], which has been demonstrated to have increased activity against PIK3CA mutant breast cancer. A one-pot Miyaura borylation, Suzuki-Miyaura coupling, and saponification to produce $\mathbf{5}$ from $\mathbf{1}$ were described. Extensive palladium catalyst screening indicated only the Buchwald XPhos G1 and G2 pre-catalysts [9] were able to achieve full conversion to boronate ester 2, with G2 selected after further optimization; $90 \mathrm{~mol} \%$ of 3, which was synthesized on a kilogram scale through four steps, and $200 \mathrm{~mol} \%$ of $1 \mathrm{M} \mathrm{LiOH}$ were added directly to the reaction vessel following borylation to carry out the Suzuki-Miyaura coupling. Remarkably, only $0.3 \mathrm{~mol} \%$ of Pd catalyst was used to perform these two steps. After full conversion to 4, more $\mathrm{LiOH}$ was added to carry out saponification. Acidification with the addition of 
aqueous $\mathrm{HCl}$ provided 5 as a solid. An $88 \%$ yield and $>98 \mathrm{~A} \%$ purity was achieved for 5 on a kilogram scale (Scheme 1). Overall, the development of this one-pot synthesis of 5 lowered the process mass intensity (PMI) of the entire route significantly from previous reports. Due to the corrosivity of $\mathrm{HCl}$ and foaming issues during acidification, the plant scale acidification was run in $n$-propanol and $\mathrm{H}_{2} \mathrm{SO}_{4}$. The use of $n$-propanol also helped to purge Pd to $<40$ ppm vs. $\sim 400 \mathrm{ppm}$.

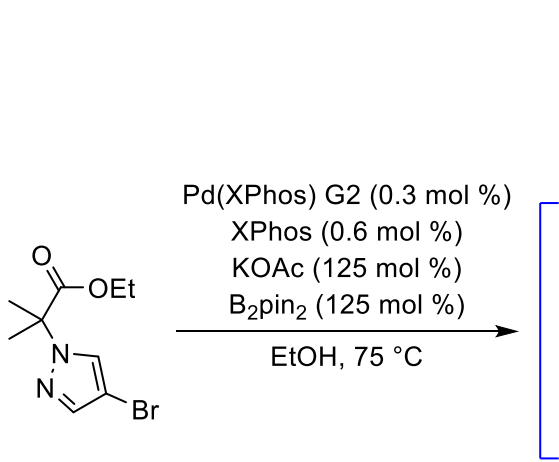

1

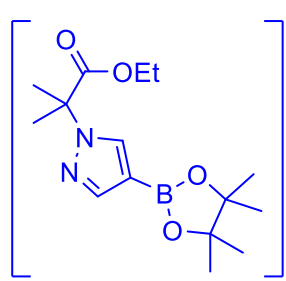

2

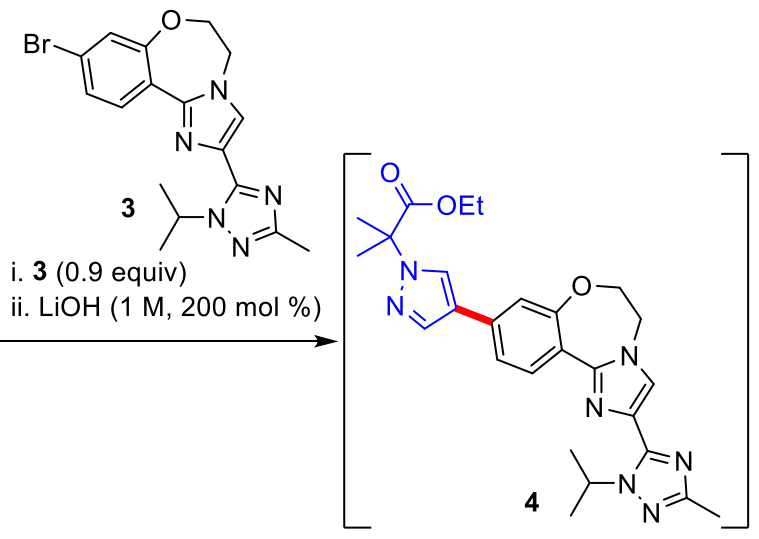

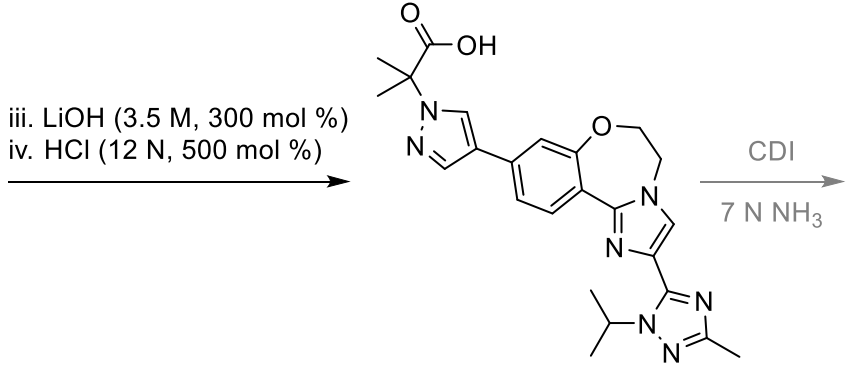

5, $88 \%$

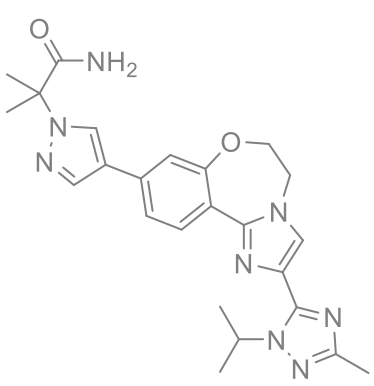

6, taselisib

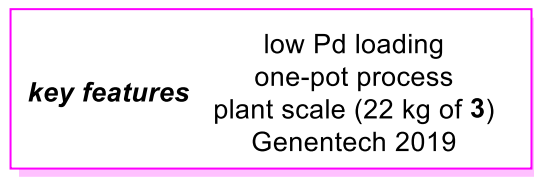

Scheme 1. Synthesis of an intermediate en route to taselisib.

Akin and coworkers [10] from Pfizer designed a new synthetic method for proprotein convertase subtilisin/kexin type 9 (PCSK9) inhibitor PF-06815345 (13) [11], a potential treatment for decreasing serum LDL-cholesterol levels and reducing the risk of coronary heart disease. The precursor to $\mathbf{1 3} \bullet \mathrm{HCl}$ is formed through a Suzuki-Miyaura coupling of intermediates $\mathbf{1 0}$ and 11. A Buchwald-Hartwig amination is involved in the first step towards synthesizing 9 , and a yield of $77 \%$ was achieved for the amination product. Optimization of the Suzuki-Miyaura coupling focused on minimizing various side products formed. The most attention was paid to a homodimer side product that was caused by higher oxygen levels of the reaction solution. Additional precautions and adaptations were made to the reaction protocol, including nitrogen purging, installing oxygen sensors, and ordering palladium catalysts from vendors in presubdivided ampules, to minimize the formation of the side product. Extensive screening also indicated that $\mathrm{Pd}(0)$ catalysts, in general, performed better than their $\mathrm{Pd}(\mathrm{II})$ counterparts, with $\mathrm{Pd}\left(\mathrm{PCy}_{3}\right)_{2}$ achieving the best results. This reaction scaled up well, achieving $>99 \%$ conversion on a kilogram scale (Scheme 2). 


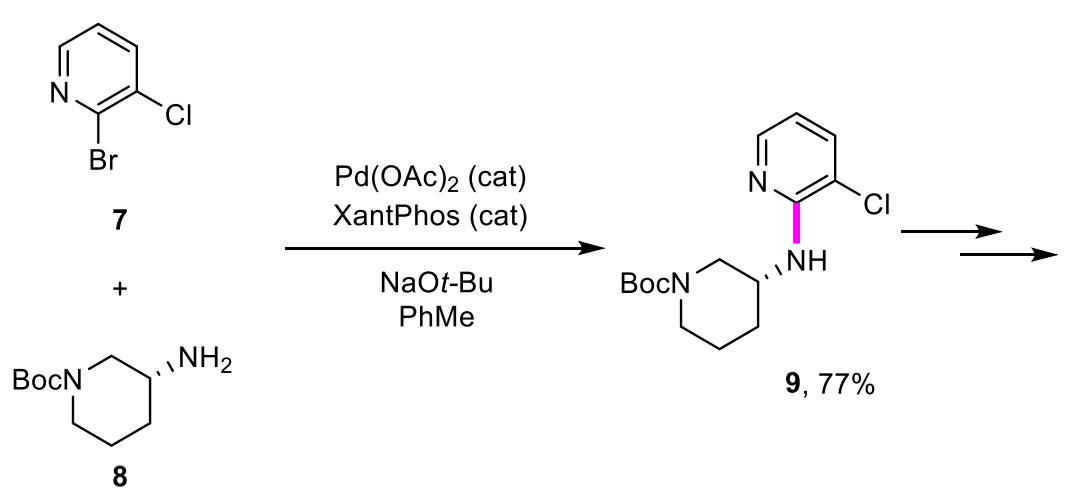<smiles>CC(C)(C)OC(=O)N1CCC[C@H](N(C(=O)c2ccc(B3OC(C)(C)C(C)(C)O3)c(F)c2)c2ncccc2Cl)C1</smiles>

10

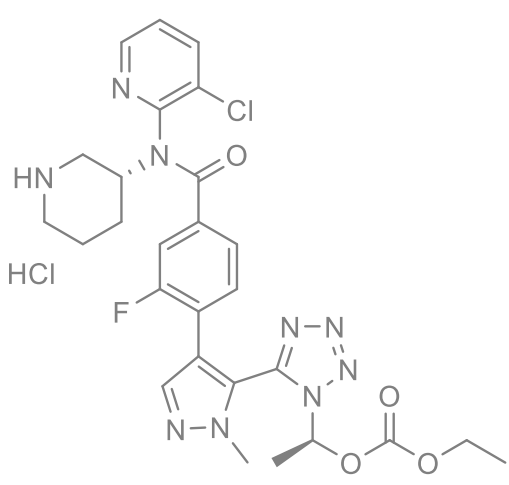

13. HCl, PF06815345

$12,75 \%$

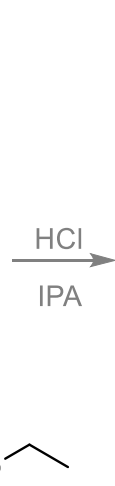

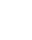

Scheme 2. Synthesis of an intermediate en route to PF06815345.

Goundry and coworkers [12] from AstraZeneca developed a large-scale synthetic route to ATR Inhibitor AZD6738 17 [13], a potential drug candidate in Phase I/II trials for treating both solid and hematological cancers. Due to time pressure, major changes were not made to the discovery route. Rather, the conditions for each chemical transformation were optimized and scaled up. The penultimate step in the synthesis of $\mathbf{1 7}$, which became the ultimate step in the new route due to the elimination of a deprotection step, is a Suzuki-Miyaura coupling to install the azaindole structure from boronate ester 16. On a kilogram scale, the catalyst system of (DTBPPS) palladium was tested as DTBPPS is a water-soluble ligand that would allow the palladium to be largely removed via aqueous washes. However, at $0.5 \mathrm{~mol} \%$ of the catalyst, the reaction stalled at $5 \%$ conversion and could not be restarted by adding more catalyst or base. Therefore, the team reverted to $\mathrm{Pd}(\mathrm{PPh})_{3} \mathrm{Cl}_{2}$ conditions. On a plant scale, a screening of catalyst and ligands showed $\mathrm{Pd}(\mathrm{dppf}) \mathrm{Cl}_{2}$ to be a superior catalyst. The $\mathrm{HCl}$ salt of $\mathbf{1 5}$ was used, which necessitated the addition of an extra equivalent of the base. The reaction used ethanol as a solvent and achieved complete conversion in $2 \mathrm{~h}$, with an average yield of $88 \%$ between three multi-kilogram batches. However, it was later found that $n$-butanol proved best for this cross coupling (Scheme 3). 
<smiles>COC(=O)c1cc(Cl)nc(Cl)n1</smiles><smiles>C[C@H]1COCCN1c1cc(C2(S(C)(=N)=O)CC2)nc(Cl)n1</smiles>

15<smiles>CC1(C)OBOC1(C)C</smiles><smiles>Brc1ccnc2[nH]ccc12</smiles>

16

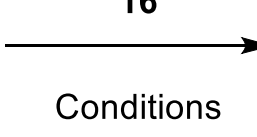<smiles>C[C@H]1COCCN1c1cc(C2([S@@](C)(=N)=O)CC2)nc(-c2ccnc3[nH]ccc23)n1</smiles>

17, AZD6738

$\begin{array}{lll}\text { scale } & \text { conditions } & \text { yield (\%) } \\ \text { Kilo } & 16(1.3 \text { equiv }), \mathrm{Pd}\left(\mathrm{PPh}_{3}\right)_{2} \mathrm{Cl}_{2}(5 \mathrm{~mol} \%) & 52-83 \\ & \mathrm{~K}_{2} \mathrm{CO}_{3}, n \text {-butanol, } 90^{\circ} \mathrm{C} & \\ \text { Plant } & 16(1.1 \text { equiv }), \mathrm{Pd}(\mathrm{dppf})_{2} \mathrm{Cl}_{2}(2 \mathrm{~mol} \%) & 65-100 \\ & \mathrm{~K}_{2} \mathrm{CO}_{3}, n \text {-butanol, } 75^{\circ} \mathrm{C}\end{array}$

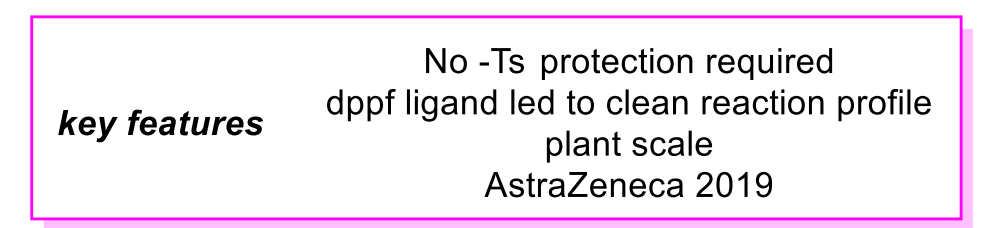

Scheme 3. Synthesis of AZD6738.

Gontcharov and coworkers [14] from Pfizer developed a robust multi-kilogram scale synthetic route for PF-06263276 23 [15]. 23 is an inhaled pan-JAK inhibitor in clinical development for the treatment of chronic obstructive pulmonary disease. A Suzuki-Miyaura coupling is required between an aryl fragment and cyano-substituted indazole to produce a key intermediate for the new synthesis route. The use of a boronic acid coupling partner 19 instead of its boronate ester was an improvement from the medicinal chemistry synthetic route as 19 was easily prepared via Grignard reaction. This eliminated the need for one Pd-catalyzed step. Side product borinic acid $\mathbf{2 0}$ was found to be as reactive as the boronic acid in the future Suzuki-Miyaura coupling, and due to the low isolated yield of $\mathbf{1 9}(<60 \%)$, the solution of $\mathbf{1 9}$ and $\mathbf{2 0}$ were telescoped into the next step. The Suzuki-Miyaura coupling proceeded smoothly, although its product, intermediate $\mathbf{2 2}$, was not able to be isolated as a crystalline solid. Thus, it was decided to telescope the solution containing 22 into the next sequence of steps. The yield for $\mathbf{2 2}$ was $86 \%$ in situ (Scheme 4). 
<smiles>CCOc1cc(Br)c(Br)cc1F</smiles>

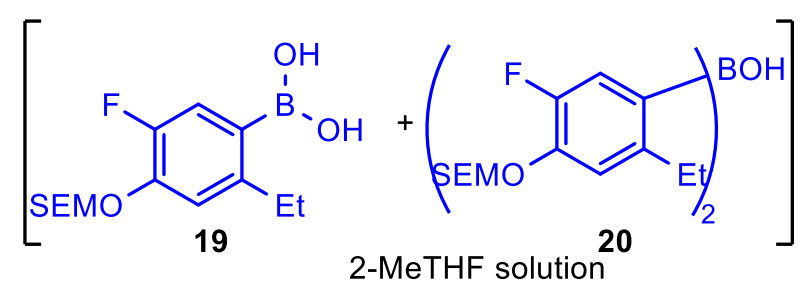<smiles>COS(=O)(=O)n1nc(C#N)c2ccc(Br)cc21</smiles>

21

$\mathrm{Pd}(\mathrm{OAc})_{2}(2 \mathrm{~mol} \%)$ dtbpf (2 mol \%)

$\mathrm{K}_{3} \mathrm{PO}_{4}$ (2 equiv.)

2-MeTHF/water

$65^{\circ} \mathrm{C}, 2 \mathrm{~h}$<smiles>CCOc1cc(CC)c(-c2ccc3c(C#N)nn(S(C)=O)c3c2)cc1F</smiles>

22, $86 \%$

\begin{tabular}{|cc|}
\hline key features & $\begin{array}{c}\text { preparation of boronic acid via aryl-Mg } \\
\text { one-pot process } \\
\text { multi-kilo scale } \\
\text { Pfizer } 2019\end{array}$ \\
\hline
\end{tabular}

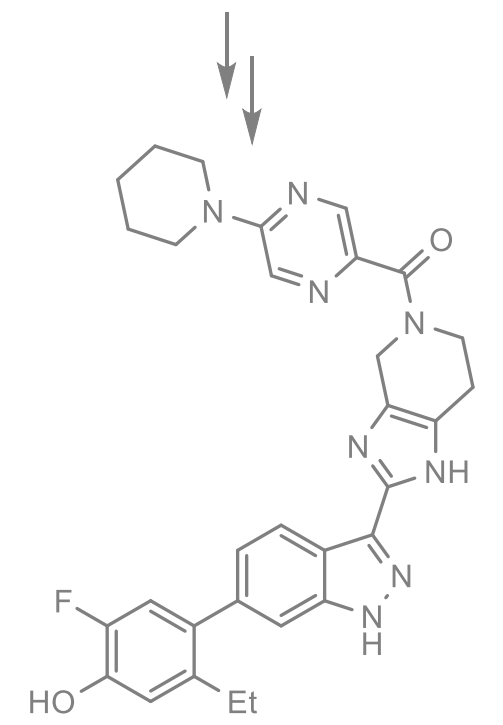

23, PF06263276

Scheme 4. Synthesis of an intermediate en route to PF06263276.

Baenziger and coworkers [16] from Novartis reported the development of a synthesis of dactolisib 27 [17], a dual kinase inhibitor of phosphatidylinositol 3-kinase (PI3K) and mammalian target of rapamycin (mTOR) currently investigated as the treatment of solid tumor forms. The coupling reaction between $\mathbf{2 5}$ and $\mathbf{2 6}$ afforded the desired product $\mathbf{2 7}$ and was optimized for commercial-scale manufacturing. The goal was to lower the palladium loading $(6 \mathrm{~mol} \%)$ to reduce cost and residual Pd levels. It was found that adding additional $\mathrm{PPh}_{3}$ (2 equiv. to Pd catalyst) as a supplementary ligand helped stabilize the catalytically active $\operatorname{Pd}(0)$ complex as well as act as a reducing agent for converting $\operatorname{Pd}(\mathrm{II})$ to $\operatorname{Pd}(0)$. On a laboratory scale, the $\mathrm{Pd}$ loading could be reduced to $<0.2 \mathrm{~mol} \%$ with a $2 \mathrm{Pd}$ equiv. addition of $\mathrm{PPh}_{3}$ but was not reported on a commercial scale. The yield of crude 27 from the Suzuki-Miyaura coupling was $>96 \%$, and the overall yield for pure 27 was $85-90 \%$ with $>99.5 \%$ purity on a multi-kilogram scale (Scheme 5 ).

Maltais and coworkers [18] from the Université Laval designed three new synthetic routes for PBRM, the first selective covalent inhibitor of $17 \beta$-hydroxysteroid dehydrogenase type 1 (17 $\beta$-HSD1) [19]. 17 $\beta$-HSD1 is involved in the last step of estrogen biosynthesis, making PBRM a leading candidate to treat breast cancer. Previous routes were only able to produce milligrams to a few grams of PBRM with long steps and low yield, so new routes that can reduce the number of steps and improve the overall yield are needed on a gram 
scale. The installation of the bromoethyl side chain was improved. Instead of arriving at 30 after multiple steps from 28, potassium (2-benzyloxyethyl) trifluoroborate was prepared from a published procedure and used as the coupling partner for $\mathbf{2 8}$ to arrive at $\mathbf{3 0}$ in one step. The coupling conditions followed previous conditions by Molander et al., who reported different examples of cross-coupling reactions of potassium alkyltrifluoroborate with aryl triflates. The yield for 30 (67\%) was similar to those published (66-75\%) (Scheme 6). The scale-up of this reaction to a multi-gram scale performed just as well as the small-scale assay. Following the development of this step, the entire synthesis of PBRM was optimized, particularly regarding reducing the amount of purification needed and improving the efficiency of other reactions in the route.

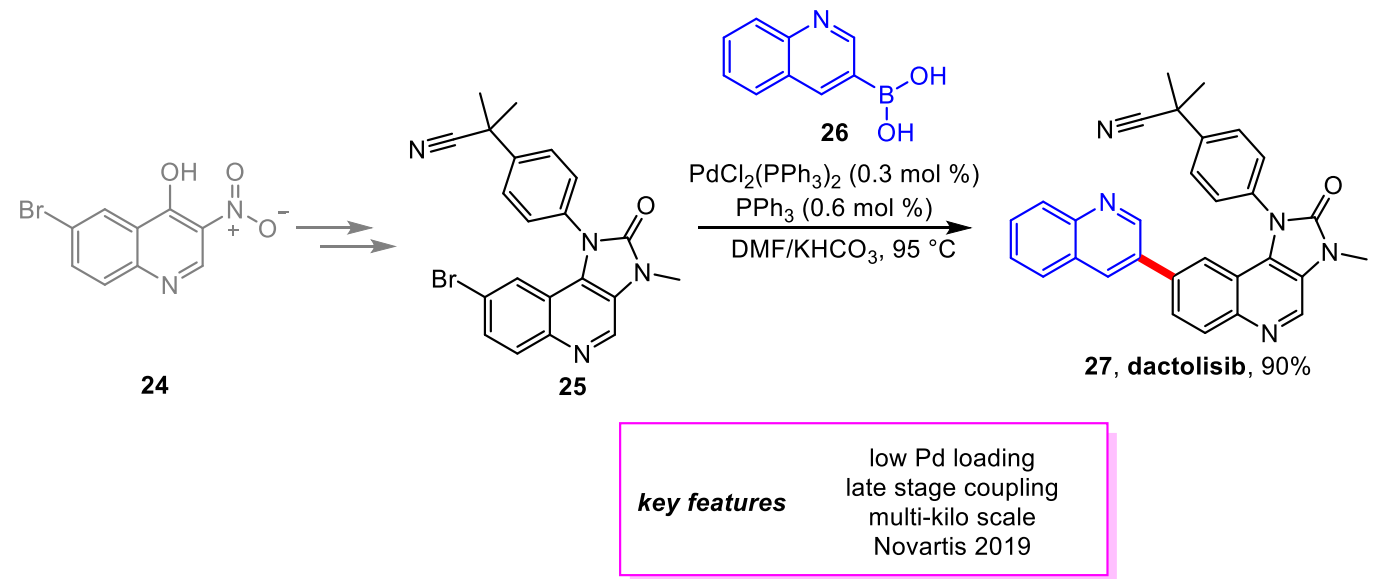

Scheme 5. Synthesis of an intermediate en route to dactolisib.<smiles>C[C@]12CC[C@H]3c4ccc(O)cc4CC[C@H]3[C@H]1CCC2=O</smiles>

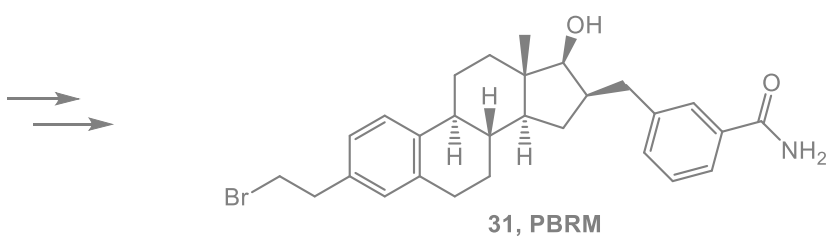

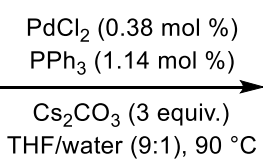

THF/water (9:1), $90^{\circ} \mathrm{C}$

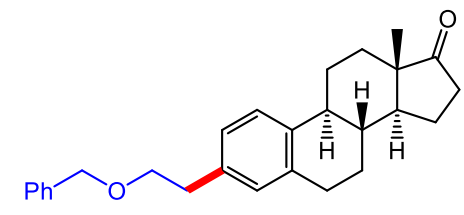

$30,67 \%$

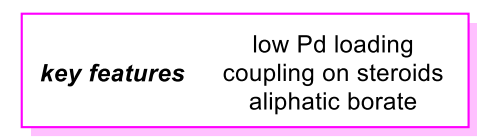

Scheme 6. Synthesis of an intermediate en route to PBRM.

Zhao and coworkers [20] of Lexicon Pharmaceuticals developed two large-scale synthetic routes for Tryptophan Hydroxylase Inhibitor LX1031, a drug candidate for treating irritable bowel syndrome (IBS) in clinical trials [21].

The first-generation process route aimed to construct the LX1031 API via coupling two penultimate intermediates pyrimidine chloride 35 and biaryl chiral alcohol 38. Intermediate 35 required a Suzuki-Miyaura coupling of boronate $\mathbf{3 3}$ and aminopyridine $\mathbf{3 4}$. Extensive screening and optimization of palladium catalyst and base were conducted to minimize the formation of various impurities. The solvent was also screened to find a relatively safe and environmentally benign solvent system that was able to perform well in the reaction. A $65 \%$ yield with $95 \mathrm{~A} \%$ purity was achieved on a $50 \mathrm{~kg}$ scale, although many batches had higher residual Pd levels than lab batches and required further recrystallization. The Suzuki-Miyaura coupling for intermediate 38 achieved a $93 \%$ yield with $>99 \%$ purity on a $120 \mathrm{~kg}$ batch without further optimization (Scheme 7, top equation). 


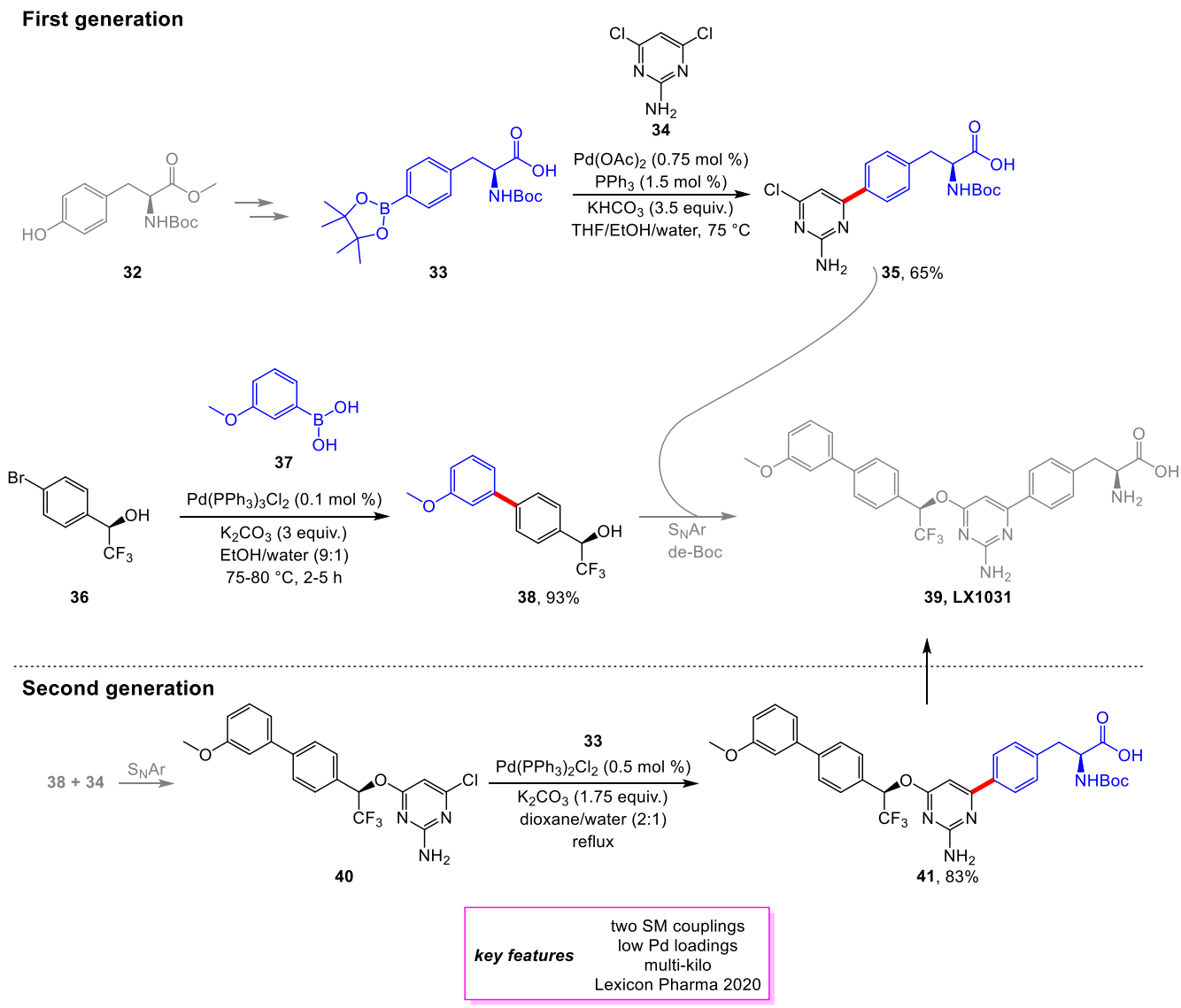

Scheme 7. Synthesis of an intermediate en route to LX1031.

The second-generation process route aimed to reduce the cost of production even further by avoiding the tedious process to produce 35 on a modest yield. Therefore, the task became optimizing the Suzuki-Miyaura coupling to form 41, the penultimate intermediate, which is converted to LX1031 via deprotection of the chiral amine. Extensive screening and optimization of the conditions improved the conversion of the sluggish reaction, and an $83 \%$ yield with $\sim 98 \%$ purity was achieved on a multi-kilogram scale. However, residual $\mathrm{Pd}$ levels proved to be an issue again, but it was found that extending the aging time by $3-5 \mathrm{~h}$ lowered the residual Pd levels drastically (Scheme 7, bottom equation).

Hardouin and coworkers [22] from Oril Industries designed a multi-kilogram scale synthesis of 45, a key intermediate towards the synthesis of 46, a Potent Dual Bcl-2/Bcl-xL Antagonist in clinical trials to treat Bcl-2 dependent malignancies such as leukemias and lymphomas [23]. An improved Suzuki-Miyaura coupling using Pd/C was explored, and optimal conditions for the reaction were determined following the extensive screening. This process had several advantages over the previous method. First, the purity of $\mathbf{4 4}$ was improved from $60-70 \%$ to $97 \%$ after extraction with toluene. Second, issues associated with intellectual property related to the phosphine ligand were avoided. Third, being able to conduct the reaction in water improved the environmental impact of the production. Overall, the yield of a penultimate intermediate required to make 46 via sulfonamide coupling has improved from 64 to $83 \%$ with the new synthetic method (Scheme 8 ). 


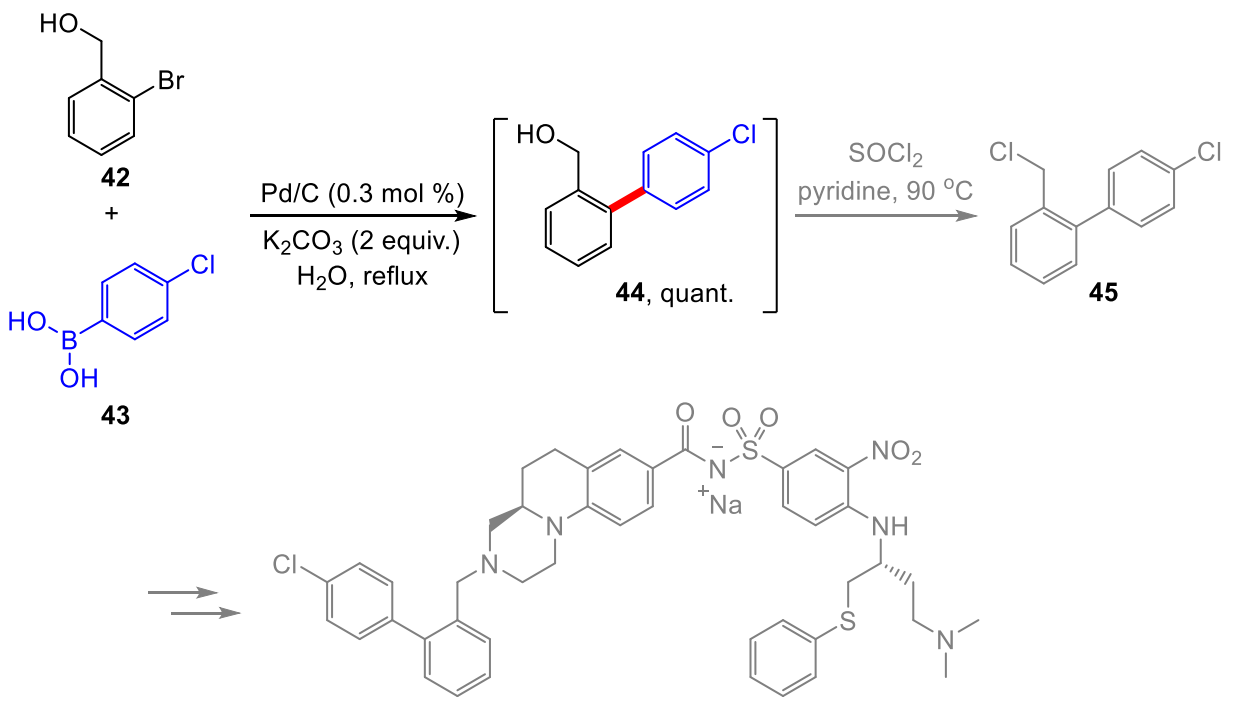

46, BCL inhibitor

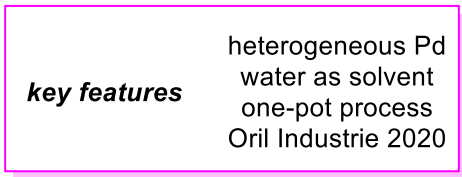

Scheme 8. Synthesis of an intermediate en route to BCL inhibitor.

Kallemeyn and coworkers [24] from AbbVie set out to design a large-scale synthetic method for a macrocycle intermediate towards the synthesis of Glecaprevir [25], a potent hepatitis $\mathrm{C}$ virus (HCV) NS3/4A protease inhibitor. Two ring-closing options for the desired macrocycle were considered. The first uses a coupling reaction, and the second uses an etherification reaction. While exploring the first option, an extensive screening was conducted for a Suzuki-Miyaura coupling of 47, and the optimal conditions were determined. However, this method was only able to achieve an $11 \%$ yield of 48 due to the tendency of $\mathbf{4 8}$ to decompose rapidly due to the instability of the allylic difluoride functionality in the presence of palladium and ligand (Scheme 9). Therefore, it would be necessary to determine conditions for forming the $\mathrm{C}-\mathrm{C}$ bond at a faster rate than the product's decomposition. This option was abandoned as the instability of the coupling product proved to be a liability for large-scale production.

Schäfer and coworkers [26] from Idorsia Pharmaceuticals developed a scalable synthetic route for the thiadiazole building block 53 to be used for a project at Idorsia Pharmaceuticals. The first-generation synthesis of 53 used Lawesson's reagent to produce the desired thiadiazole moiety, which hindered the scalability of the route. The new route starts with 50, a bench-stable compound with commercial availability on a kilogram scale. The final product was afforded following a Sandmeyer bromination and Suzuki-Miyaura coupling. Screening of the Suzuki-Miyaura coupling determined the optimal conditions for the reaction on a gram scale, which, notably, includes the ability to perform the reaction at room temperature. Upon scale-up to a $1.0 \mathrm{~kg}$ scale, it was discovered that a greater loading $(3.0 \mathrm{~mol} \%)$ of $\mathrm{Pd}(\mathrm{OAc})_{2} /$ XantPhos and longer reaction time $(24 \mathrm{~h})$ was needed to achieve full conversion of the 51. This was due to time pressure for the project, which prevented performing full purification of the $\mathrm{kg}$ scale batch of $\mathbf{5 1}$ to remove residual $\mathrm{Cu}$ catalysts from the Sandmeyer bromination, in turn interfering with the Pd catalyst system. On the $\mathrm{kg}$ scale, a $61 \%$ yield was achieved for the Suzuki-Miyaura coupling, while with additional purification of 51, an $85 \%$ yield was achieved on a $200 \mathrm{~g}$ scale with the screening conditions (vide supra) (Scheme 10). 
<smiles>[Z17][C@H](NC(=O)O[C@H]1CCC[C@@H]1OC/C=C/B1OC(C)(C)C(C)(C)O1)C(=O)N1C[C@H](Oc2nc3ccccc3nc2C(F)(F)Br)C[C@H]1C(=O)OC</smiles>

$\mathrm{Pd}_{2}(\mathrm{dba})_{3}(1.5 \mathrm{~mol} \%)$

$\underset{\mathrm{K}_{3} \mathrm{PO}_{4}(2 \text { equiv) }}{\longrightarrow}$

$\mathrm{DME} / \mathrm{H}_{2} \mathrm{O}(20: 1), 50{ }^{\circ} \mathrm{C}$

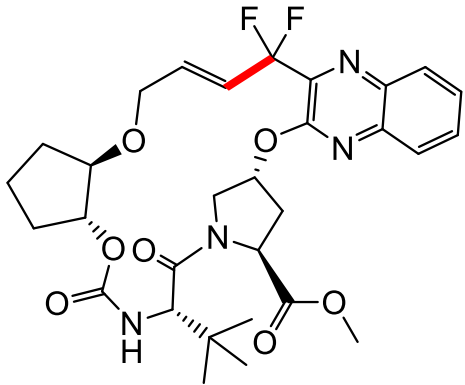

48, $11 \%$

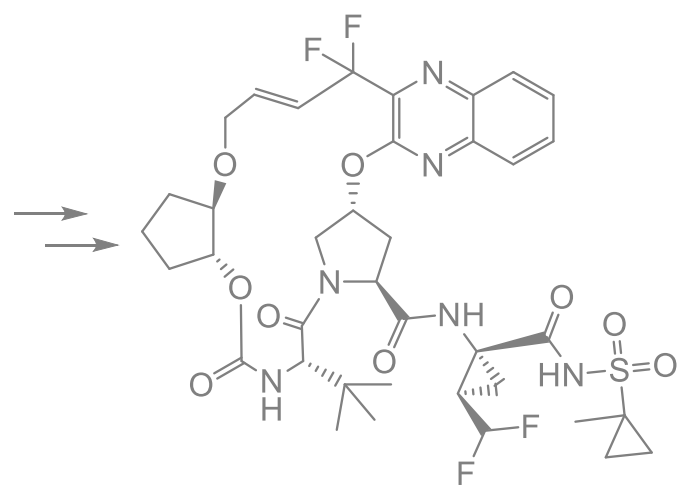

\begin{tabular}{|cc|}
\hline & intramolecular coupling \\
key features & $\mathrm{sp}^{3}$ halide \\
vinyl boron \\
AbbVie 2020
\end{tabular}

49, Glecaprevir

Scheme 9. Synthesis of an intermediate en route to glecaprevir.

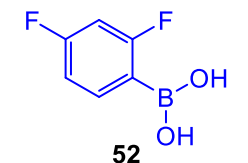<smiles>CCOC(=O)c1nnc(Br)s1</smiles>

51<smiles>[CH]1CCC1</smiles><smiles>CCOC(=O)c1nc(N)sc1CC</smiles>

50
$\mathrm{Pd}(\mathrm{OAc})_{2} /$ Xantphos (1.0 mol \%) NMM (2.2 equiv.)

Toluene (8V), $\mathrm{H}_{2} \mathrm{O}(4 \mathrm{~V})$

$\mathrm{rt}, 7 \mathrm{~h}$

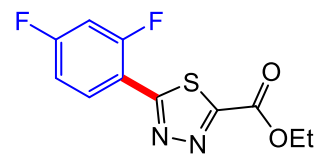

53, $85 \%$ yield<smiles>C=[Te]</smiles>

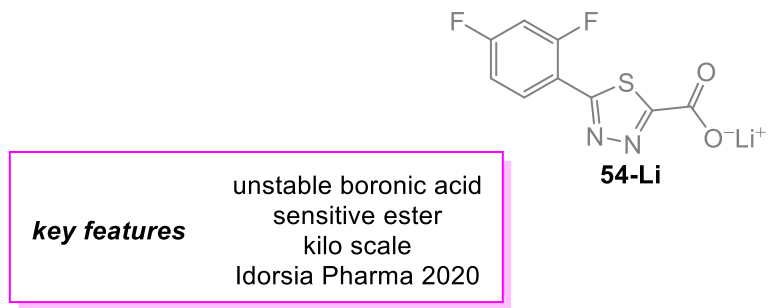

Scheme 10. Synthesis of thiadiazole intermediate.

Zhang and coworkers [27] from the Chinese Academy of Science designed a novel method for synthesizing crucial intermediate to lumacaftor $\mathbf{5 9}$ [28], the active ingredient of treatment for cystic fibrosis, that increases the overall yield and decreases the environmental impact. Instead of introducing chlorines and amines like previous methods, the starting material 55 in the new route already contained the chlorine and amine in their proper positions. A Suzuki-Miyaura coupling is then used to introduce the 5-methyl group 
with regioselectivity. An extensive screening was conducted to determine the optimal conditions for minimizing impurities as a result of hydrolysis of acetyl groups on $\mathbf{5 6}$ and $\mathbf{5 8}$ or debromination of 58 . The coupling step achieved an $82 \%$ yield on a scale of over $300 \mathrm{~g}$ (Scheme 11).

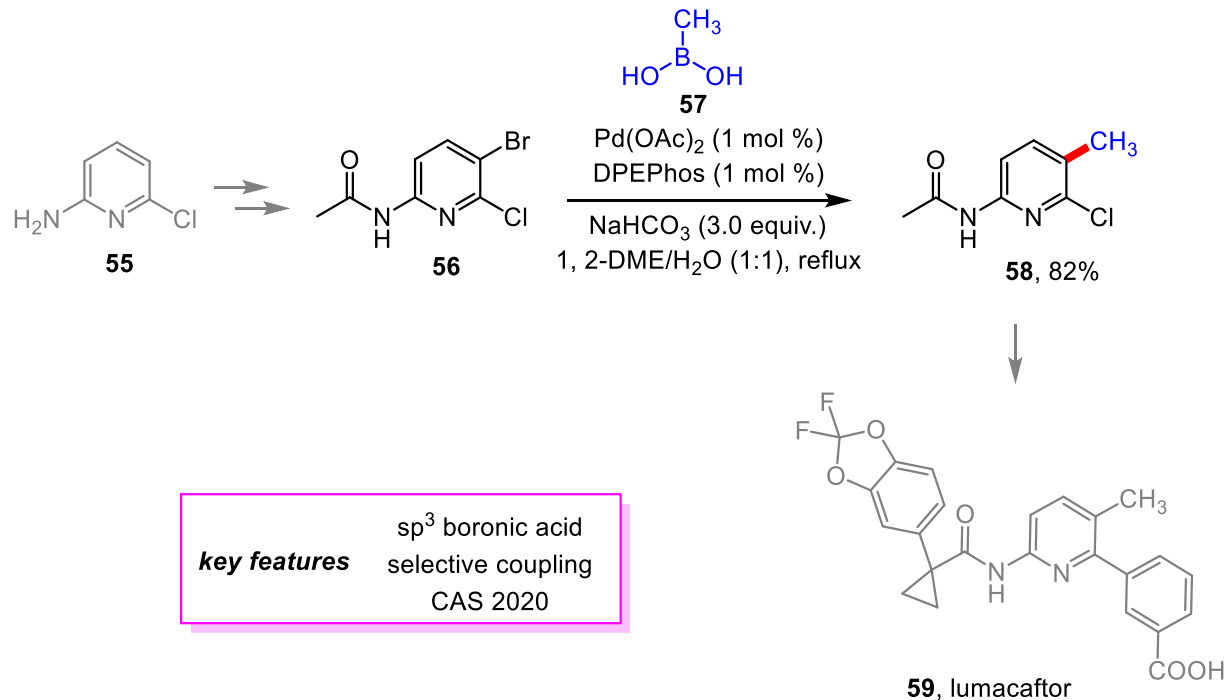

Scheme 11. Synthesis of an intermediate en route to lumacaftor.

Smith and coworkers [29] from Bristol Myers Squibb developed a scalable synthetic method for BMS-929075, 63, a therapy drug in clinical trials for the hepatitis C virus infection [30]. Among the improvements was a search for an alternate coupling partner to $\mathbf{6 1}$ that would elevate the yield of late-stage intermediate $\mathbf{6 2}$. Bromo benzofuran $\mathbf{6 0}$ was found to be an ideal coupling partner. The above Suzuki-Miyaura coupling produced intermediate 62 in an 85\% yield, an increase from 58\% of the previous method, on a decagram scale. Following an amide coupling, 62 is converted to BMS-929075, 63. The overall yield for this route was 30\%, producing $110 \mathrm{~g}$ of high-quality BMS-929075 (Scheme 12).

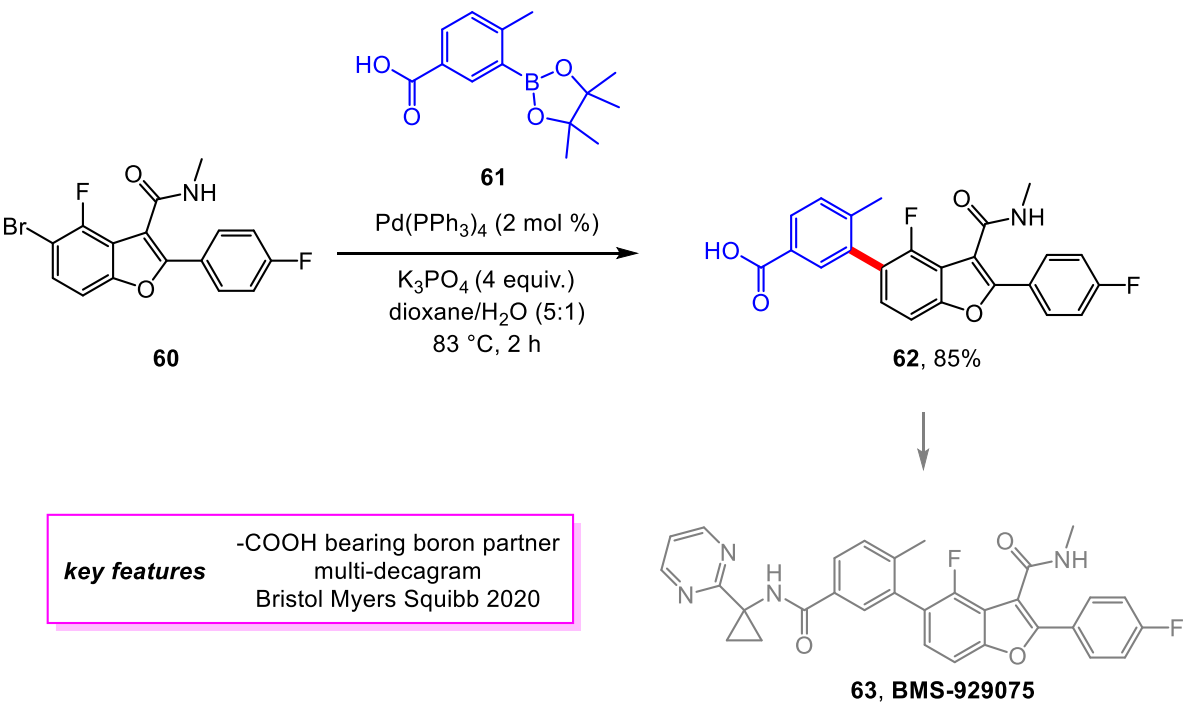

Scheme 12. Synthesis of an intermediate en route to BMS-929075.

Baenziger and coworkers [31] from Novartis developed synthetic methods for streamlined large-scaled manufacturing of LSZ102 [32], a selective estrogen receptor degrader drug candidate for treating breast cancer. The new methods significantly improved the overall yield and reduced the cost. The important Suzuki-Miyaura coupling, also the 
final step in the original synthesis route, was optimized to minimize the formation of the main side product by reducing the temperature of the reaction and changing the solvent. The extensive screening was also conducted for a superior catalyst system, but none was found to perform better than the original. A $62 \%$ yield on this Suzuki-Miyaura coupling product 68 was achieved. Alternate routes to intermediates 66 and 67 were also described (Scheme 13).

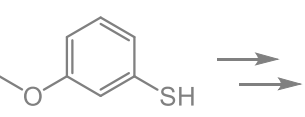

64

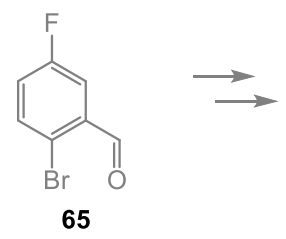

65

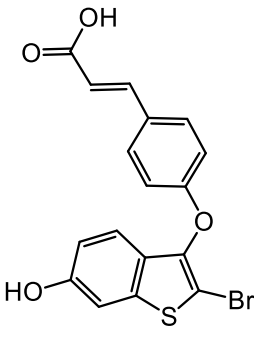

66

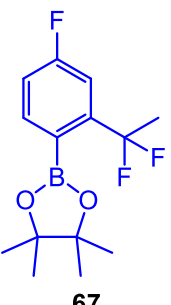

67

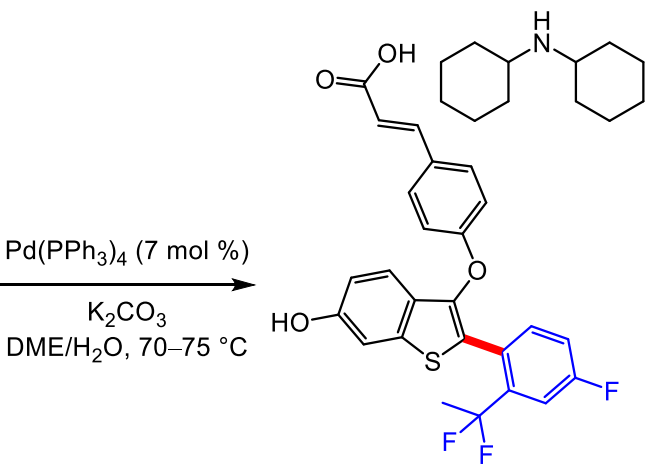

Crude 68, 62\%

Isolation and Purification

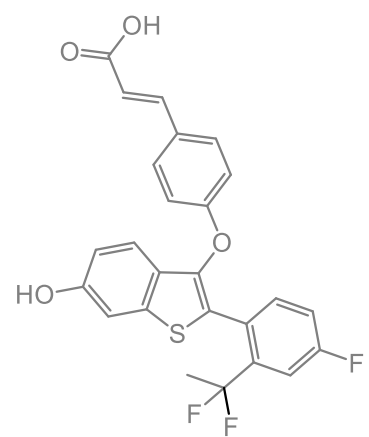

68, LSZ102

Scheme 13. Synthesis of LSZ102.

Parmentier and coworkers [33] from Novartis developed a kilogram-scale protocol for the final step in the synthesis of LSZ102 [32], a drug candidate for treating breast cancer. The Suzuki-Miyaura coupling can now be carried out using the designer surfactant TPGS-750$M$ [34] to reduce the environmental impact and cost of this reaction. Less Palladium catalyst and non-toxic organic solvents are needed. Further, the use of acetone as a co-solvent and the addition of $\mathrm{LiBr}$ lowered the required excess loading of boronate ester $\mathbf{6 7}$ to achieve desirable conversion. The main impurity was also controlled effectively, reduced to $<0.1 \%$ compared to the usual $7-8 \%$ found in the crude mixture. Notably, the palladium loading was also lowered to $1.5 \mathrm{~mol} \%$ of $\mathrm{PdCl}_{2}$ (dtbpf) from $7.5 \mathrm{~mol} \%$ of $\mathrm{Pd}\left(\mathrm{PPh}_{3}\right)_{4}$ (Scheme 14). 


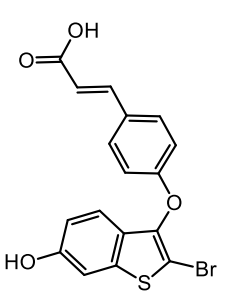

66

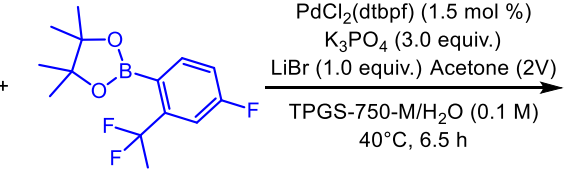

67

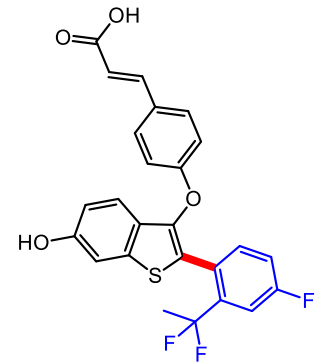

68, LSZ102

$$
\begin{array}{|c|c|}
\text { water as solvent } \\
\text { key features } & \begin{array}{c}
\text { bulky boron partner } \\
\text { late stage coupling } \\
\text { Novartis } 2020
\end{array}
\end{array}
$$

Scheme 14. Synthesis of LSZ102 in aqueous surfactant.

Graham and coworkers [35] from AstraZeneca developed an improved manufacturing route to ceralasertib 71 [13], an ATR inhibitor currently tested as a drug for treating cancer. The new method features an improved Suzuki-Miyaura coupling between $\mathbf{7 0}$ and $\mathbf{1 6}$ that simplifies the workup and crystallization required by simply performing a solvent swap to 2-methyltetrahydrofuran (2-MeTHF). This Suzuki-Miyaura coupling and crystallization process achieved a $70 \%$ yield of ceralasertib with great control of residual Palladium ( $<3 \mathrm{ppm}$ in all batches) and impurities on a scale of $32 \mathrm{~kg}$. The overall yield of this route was $16 \%$ (Scheme 15$)$.

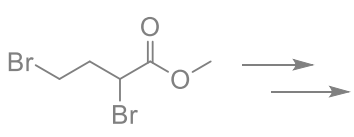

69

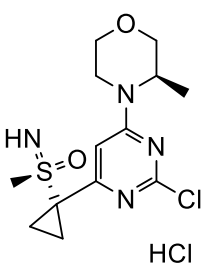

70

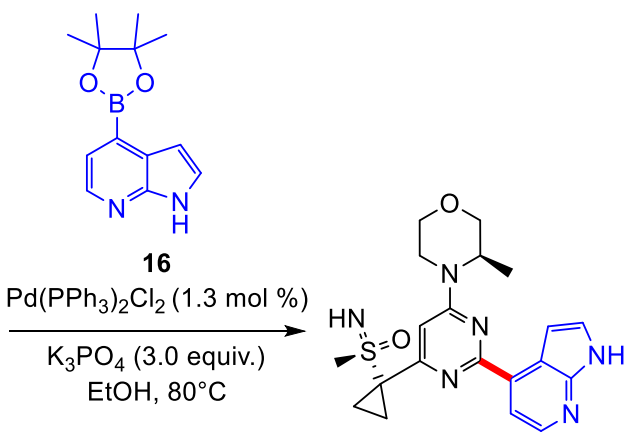

71, ceralasertib

$$
\begin{array}{|lc|}
\hline \text { key features } & \begin{array}{c}
\text { unprotected azaindole } \\
\text { plant scale (33 kg) } \\
\text { late stage coupling } \\
\text { AstraZeneca 2021 }
\end{array} \\
\hline
\end{array}
$$

Scheme 15. Synthesis of ceralasertib.

Xie and coworkers [36] from Sunshine Lake Pharma developed a new synthetic process for emitasvir (DAG181) 76, a novel hepatitis C treatment drug that can be applied to the kilogram scale and increases the overall yield of the target active pharmaceutical ingredients from 17 to $40 \%$. The above Suzuki-Miyaura coupling reaction produces the important intermediate $\mathbf{7 4}$ in the synthesis route and a side product $\mathbf{7 5}$, which is easily converted to the desired hydrolysis product 75 via the addition of $\mathrm{K}_{2} \mathrm{CO}_{3}$. Extensive screening of conditions showed that mild bases provided better conversion than strong bases due to the tendency of strong bases to hydrolyze $\mathbf{7 2}$ into a compound that could not participate in the Suzuki-Miyaura coupling. The effective yield $(\mathbf{7 4}+\mathbf{7 5})$ was $91 \%$. Similar conditions are used for a later Suzuki-Miyaura coupling, with the only exception being using $\mathrm{K}_{2} \mathrm{CO}_{3}$ instead of $\mathrm{NaHCO}_{3}$ as the base (Scheme 16). 


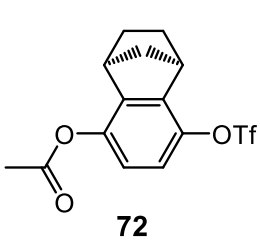

72

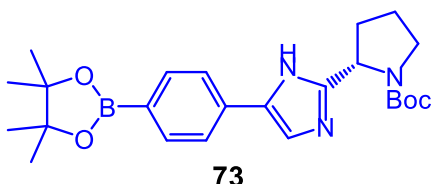

73

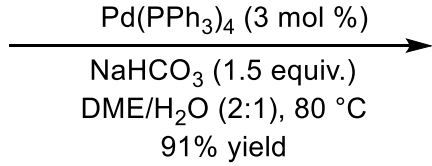

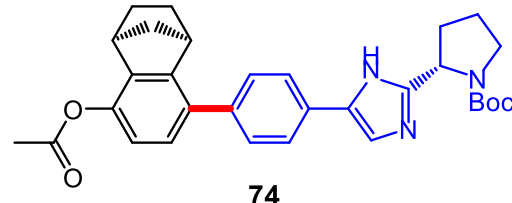

74

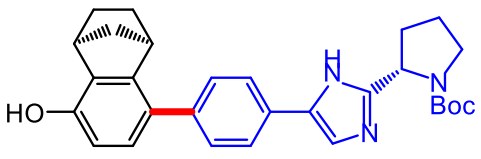

75
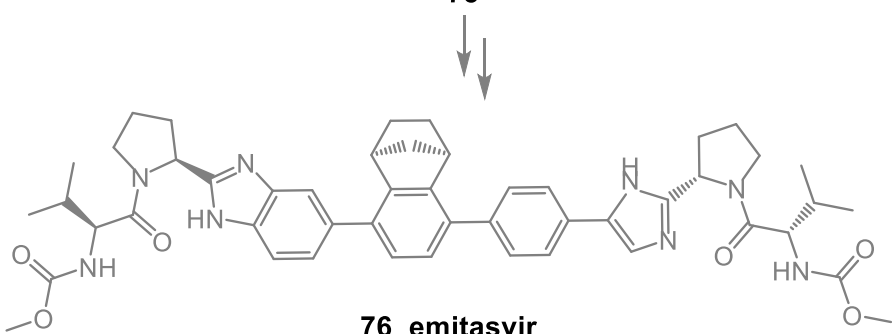

76, emitasvir

ArOTf electrophile late stage coupling Sunshine Lake Pharma 2021

Scheme 16. Synthesis of an intermediate en route to emitasvir.

\section{Buchwald-Hartwig Coupling}

The amines are an integral part of pharmaceutical compounds [37]. Traditionally, such $\mathrm{C}\left(\mathrm{sp}^{2}\right)-\mathrm{N}$ bonds are formed using copper-catalyzed Goldberg [38] and Ullmann processes [39] or $\mathrm{S}_{\mathrm{N}} \mathrm{Ar}$ (if the aryl halide is highly electrophilic). There are several pitfalls in these processes, especially poor substrate scope. These processes mostly fail to reproduce in making complex pharmaceuticals that bear several Lewis basic atoms (such as $\mathrm{N}, \mathrm{O}$, $\mathrm{S}$, etc.). $\mathrm{S}_{\mathrm{N}} \mathrm{Ar}$ reactions require special activated reactants and, most of the time, polar aprotic solvents such as DMF. Although Migita discovered [40] the initial Pd catalyzed C-N bond formation, it was not greatly explored due to poor substrate scope and the use of toxic amino stannanes. In 1994, Buchwald [41] and Hartwig [42] independently reported Pd catalyzed C-N bond formation. This breakthrough and the subsequent utilization of this reaction led to a well-known name reaction "Buchwald-Hartwig amination". The utility of this reaction is so broad that scientists can confidently forge the C-N bond at the late stage of the API synthesis. For instance, Tao and coworkers from Pfizer [43] have developed an improved synthetic route to Irreversible Epidermal Growth Factor Receptor (EGFR) T790 M [44] Inhibitor 81, a lead candidate for treating non-small cell lung cancer. A thorough small-scale screening of catalysts, bases, and solvents for the BuchwaldHartwig Amination to form intermediate $\mathbf{8 0}$ was conducted. Out of four catalysts screened, $t$-BuXPhos Palladacycle was the only catalyst that achieved full conversion with few impurities. $t-\mathrm{AmOH}$ was shown to be the optimal solvent and $\mathrm{DBU}$ to be the optimal base for achieving full conversion in $2 \mathrm{~h}$. Catalyst loading was lowered to $3 \mathrm{~mol} \%$ upon final optimization, and full conversion of starting material was achieved in $1 \mathrm{~h}$ under a nitrogen atmosphere. A $75 \%$ isolated yield of 80 isopropanol solvate (1:1) was achieved with $94 \%$ UPLC purity on a hundred-gram scale (Scheme 17). 


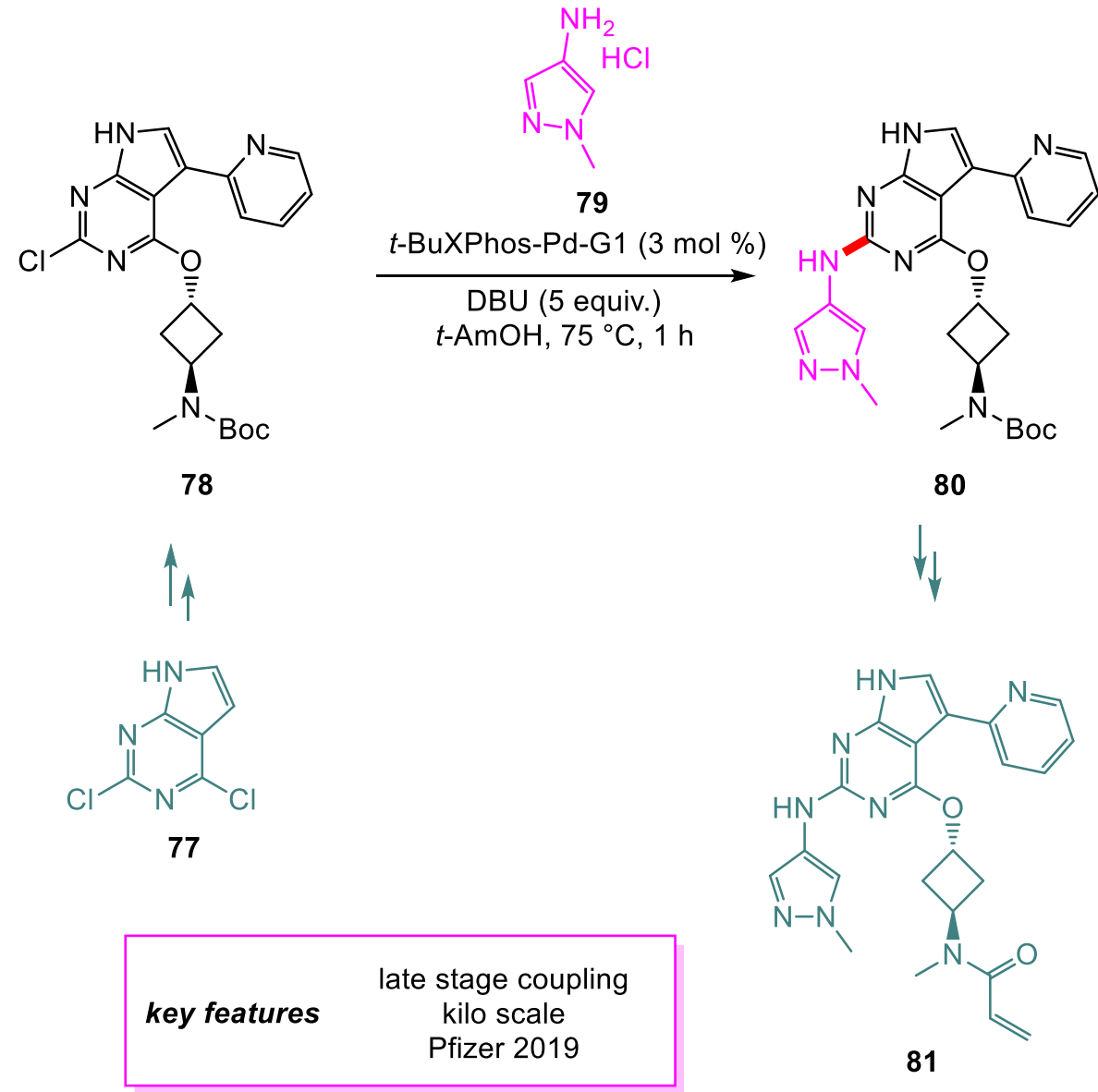

Scheme 17. Synthesis of an intermediate en route to T790 M.

Nonoyama and coworkers from Sumitomo Dainippon Pharma [45] have developed several new routes to $\mathbf{8 4}$, a potential renin inhibitor and precursor to its more membranepermeable prodrug, that improved upon the efficiency and cost of the discovery route. Plasma renin activity (PRA) plays an important role in the pathogenesis of hypertension, and inhibition of PRA can lower the risk of myocardial infarction in patients suffering from hypertension. In the second-generation route, the formation of the benzoxazine core was accomplished through an intermolecular Buchwald-Hartwig coupling. Extensive screening of reaction conditions was conducted to minimize the formation of side products while maximizing the conversion of $82 . \mathrm{Pd}\left(\mathrm{PtBu}_{3}\right)_{2}$ as a catalyst, $\mathrm{K}_{2} \mathrm{CO}_{3}$ as a base, and DMF as a solvent were selected. Upon scale-up, however, it was discovered that different lots of $\mathrm{Pd}\left(\mathrm{PtBu}_{3}\right)_{2}$ performed differently, so $5.0 \mathrm{~mol} \%$ of catalyst was used instead of $2.5 \mathrm{~mol} \%$ to prepare the needed material. This reaction achieved $6.4 \mathrm{~kg}$ of 83 in $75 \%$ isolated yield with $>99 \%$ HPLC purity. The team then investigated the formation of $\mathrm{Pd}\left(\mathrm{Pt}-\mathrm{Bu}_{3}\right)_{2}$ in situ to address the inconsistency of catalytic activity with different lots. $\mathrm{Pd}(\mathrm{OAc})_{2}$ and $3 \mathrm{Pd}$ equiv. of $\mathrm{Pt}_{-} \mathrm{Bu}_{3}$ in xylene was found to achieve the optimal catalytic activity. A $96 \%$ yield of 83 on a multi-kilogram scale with $>99 \%$ HPLC purity was achieved with this protocol (Scheme 18). However, future generations of synthetic routes were developed to improve the overall yield of $\mathbf{8 4}$ and address issues with other steps in this generation. The Buchwald-Hartwig coupling step was ultimately eliminated in favor of other ways to achieve the benzoxazine core. 


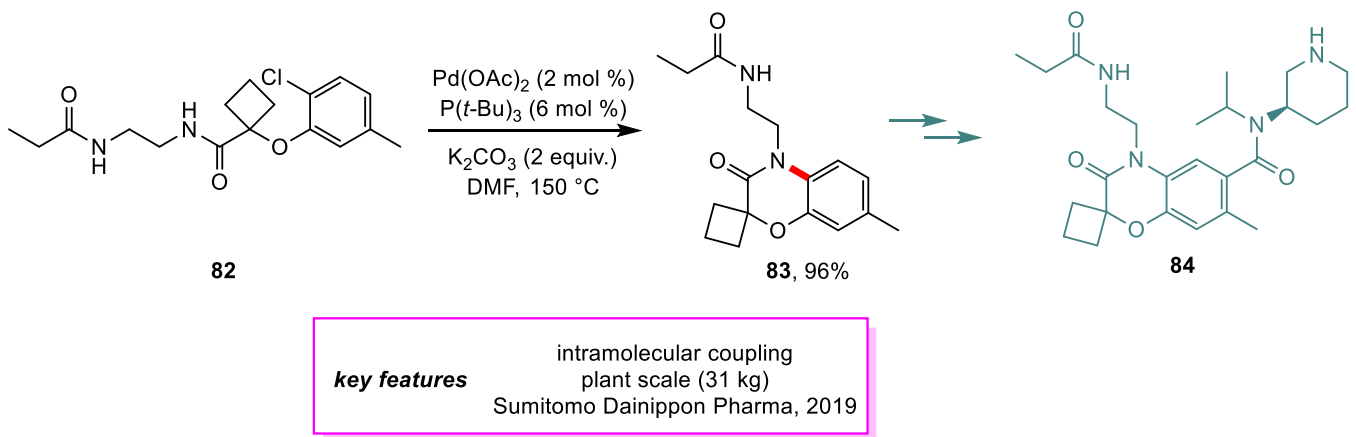

Scheme 18. Synthesis of an intermediate en route to 84 .

Carroll and coworkers from Eli Lilly [46] have developed a synthetic route towards 89 . It is an important intermediate for the synthesis of abemaciclib $\mathbf{9 0}$ (trade name Verzenio), a small-molecule CDK4/6 inhibitor approved for the treatment of hormone-receptorpositive, HER2-negative metastatic, or advanced-stage breast cancer as a monotherapy, in combination with fulvestrant, or a nonsteroidal aromatase inhibitor. The aim was primarily to avoid expensive starting material, harsh amination conditions, and many recrystallizations leading to low yield. Following optimizing the $\mathrm{S}_{\mathrm{N}} 2$ reaction to form 87 , the Buchwald-Hartwig Amination to form 89 by using LiHMDS was explored to install a protected amine, preventing the formation of undesired impurities. It was found after the extensive screening that phosphine ligands with substituents in the ortho positions of the lower aryl ring performed better than those that lacked those substituents. RuPhos was the only such ligand screened that provided the desired conversion with lower loadings of palladium. A screening of the $\mathrm{Pd}(\mathrm{II})$ source with $\mathrm{RuPhos}$ showed that $\mathrm{PdCl}_{2}(\mathrm{PhCN})_{2}$ was capable of providing complete conversion. RuPhos $/ \mathrm{PdCl}_{2}(\mathrm{PhCN})_{2}$ was selected over $\mathrm{Pd}$ 171 (Johnson Matthey precatalyst, RuPhos $\mathrm{Pd}(\mathrm{crotyl}) \mathrm{Cl}$ ), which achieved full conversion at an even lower loading of palladium $(0.25 \mathrm{~mol} \%)$ due to the former's availability. Following deprotection of $\mathbf{8 9}$, the respected 2-amino pyridine was produced on a kilogram scale with a $75 \%$ yield (Scheme 19).<smiles>ClCc1ccc(Cl)nc1</smiles>

85

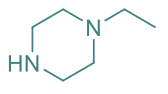

86

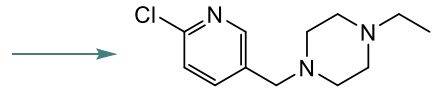

87

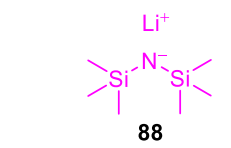

$\mathrm{PdCl}_{2}[\mathrm{PhCN}]_{2}(0.5 \mathrm{~mol} \%)$

RuPhos (1 $\mathrm{mol} \%$ )

toluene, reflux

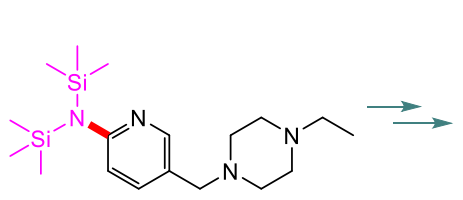

$89,75 \%$

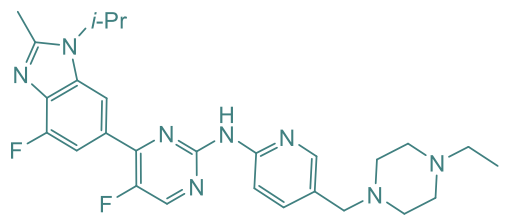

90, abemaciclib

$$
\begin{array}{|c|c|}
\hline \text { key features } & \begin{array}{c}
\text { disilazane as nucleophile } \\
\text { kilo scale } \\
\text { Eli Lilly, } 2019
\end{array}
\end{array}
$$

Scheme 19. Synthesis of an intermediate en route to abemaciclib.

$\mathrm{Li}$ and coworkers [47] from Biogen have developed a large-scale synthetic method for BIIB068 95, a potent Bruton's tyrosine kinase (BTK) that can provide therapy to patients with autoimmune diseases, as a Hemi-Adipate Co-crystal. The process development improved on various aspects of the discovery route, the first being the formation of the $\mathrm{C}-\mathrm{N}$ bond 
between intermediates 91 and 92 (Scheme 20). The discovery route employed a BuchwaldHartwig amination (same reagents as Table 1, entry 1) and carried out deprotection of $\mathbf{9 3}$ in a subsequent step following chromatography. After screening, it was discovered that neither the palladium catalyst nor 1,4-dioxane as a solvent was needed for the coupling of 91 with 92. Upon optimization, organic bases such as DIEA afforded 93 in $60 \%$ yield (entry 2). However, it was also found that, under acidic conditions, the coupling reaction and the deprotection of $\mathbf{9 3}$ to form $\mathbf{9 4}$ can be carried out in one pot, and a $91 \%$ yield of 94 was achieved with 3 equiv. of $\mathrm{H}_{3} \mathrm{PO}_{4}$ (entry 3). Using the $\mathrm{HCl}$ salt of 92 instead of free base 92 was also examined, and it was discovered that the $\mathrm{HCl}$ generated from $\mathbf{9 2 \bullet} \mathbf{H C l}$ was sufficient to drive the deprotection reaction. Further optimization also revealed that using a mixture of 2-butanol and water as a solvent eliminated the butylated impurity. The optimal conditions achieved a 95\% yield of 94 (entry 4).<smiles>Cc1cc(-c2ccnc(Cl)n2)ccc1CNC(=O)OCc1ccccc1</smiles>

91<smiles></smiles><smiles>Cc1cc(-c2ccnc(Nc3cnn(C)c3)n2)ccc1CNC(=O)OCc1ccccc1</smiles><smiles>Cc1cc(-c2ccnc(Nc3cnn(C)c3)n2)ccc1CN</smiles>

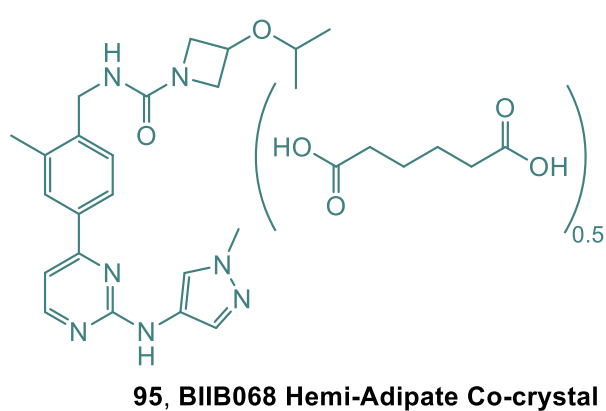

Scheme 20. Synthesis of an intermediate en route to BIIB068.

Table 1. Selected screening results for the C-N coupling of 91 with 92.

\begin{tabular}{|c|c|c|c|c|c|}
\hline \multirow[b]{2}{*}{ Entry } & \multirow[b]{2}{*}{ Reagents } & \multirow[b]{2}{*}{ Solvent } & \multirow[b]{2}{*}{$\mathrm{T}\left({ }^{\circ} \mathrm{C}\right)$} & \multicolumn{2}{|c|}{ Yields (HPLC Area \% } \\
\hline & & & & 93 & 94 \\
\hline 1 & $\begin{array}{c}\left.\mathrm{Pd}_{2}(\mathrm{dba})_{3} \text { ( } 0.2 \text { equiv. }\right) \\
\mathrm{S}-\mathrm{Phos}(0.1 \text { equiv. }) \\
\mathrm{Cs}_{2} \mathrm{CO}_{3} \text { ( } 2 \text { equiv.) }\end{array}$ & 1,4-dioxane & 100 & 58 & 0 \\
\hline 2 & DIEA ( 2 equiv.) & 1-butanol & 100 & 61 & $<1$ \\
\hline 3 & $\mathrm{H}_{3} \mathrm{PO}_{4}$ (3 equiv.) & 1-butanol & 100 & 0 & 91 \\
\hline $4^{\mathrm{a}}$ & None & $\begin{array}{l}\text { 2-butanol/ } \\
\text { water (2:3) }\end{array}$ & 85 & 0 & 95 \\
\hline
\end{tabular}

Sirois and coworkers [48] from Genentech have developed a method for producing drug candidate GDC-0022 99, an inhibitor of the Retinoid-related orphan receptor $\gamma$ (RORc), on a multi-kilogram scale. One of the major problems that was addressed from the discovery synthesis route was improving the late-stage Buchwald-Hartwig amination between 97 and 98 to preserve the stereochemical purity of the sultam moiety while improving the overall conversion. Using free base 98 instead of its bis- $\mathrm{HCl}$ salt afforded less undesired diastereomer impurities. Extensive screening and optimization of the coupling conditions also improved the purity of the desired product and overall conversion. It was found 
that the addition of KOAc allowed the reaction to be performed with lower loadings of palladium. The behavior of the reaction was studied with reaction progress kinetic analysis with interesting findings regarding the role of KOAc and the effects of biphosphine monoxide ligands. The final yield of $>5 \mathrm{~kg}$ of GDC-0022•pTsOH 99 synthesized was $58 \%$ with $>98 \mathrm{~A} \%$ purity (Scheme 21).<smiles>CC1CC[C@@H](c2ccccc2)S(=O)(=O)N1Cc1cc(F)c(Br)cc1F</smiles>

97

$\uparrow$<smiles>CC1CCC(c2ccccc2)S(=O)(=O)N1</smiles>

96

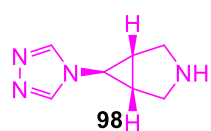

Xantphos-Pd-G2 (1 mol \%)

$\mathrm{K}_{3} \mathrm{PO}_{4}(1.5$ equiv.) $\mathrm{KOAc}(10 \mathrm{~mol} \%$ relative to 97$)$

1,4-dioxane, $100^{\circ} \mathrm{C}$

Isolation and Purification

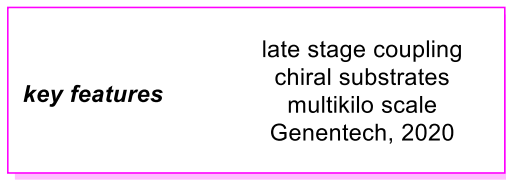

Scheme 21. Synthesis of an intermediate en route to GDC-0022.

Lei and coworkers [49] from the Shenyang Pharmaceutical University have developed a novel method for producing autotaxin inhibitor ziritaxestat 104, a drug used to treat patients with idiopathic pulmonary fibrosis or chronic obstructive pulmonary diseases. Various aspects of the previous synthetic routes were improved upon, aiming to lower the cost of production. The Buchwald-Hartwig amination to achieve penultimate intermediate 101 was modified by using free piperazine 102 instead of N-Boc piperazine [50] to skip the deprotection step and improve the overall yield of 103. It was found that the original conditions for the coupling were optimal for the new coupling after extensive screening. This step of the new synthesis route could be achieved on a 300-400 g scale (Scheme 22).

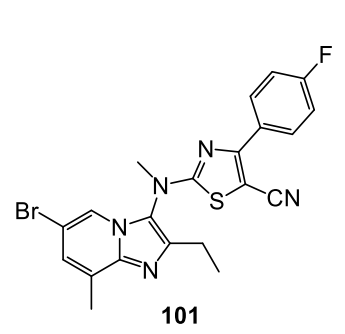

101<smiles>Cc1cc(Br)cnc1N</smiles>

100

$$
\begin{array}{cc}
\text { key features } & \text { late stage coupling } \\
\text { free piperazine } \\
\text { Shenyang Pharma Uni, 2020 }
\end{array}
$$

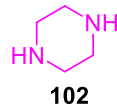

$\mathrm{Pd}_{2}(\mathrm{dba})_{3}(0.97 \mathrm{~mol} \%)$ $\underset{\text { JohnPhos }(1.9 \mathrm{~mol} \%)}{\longrightarrow}$

$\mathrm{NaOt}$-Bu (2 equiv.) toluene, $110^{\circ} \mathrm{C}$

$103,82.7 \%$

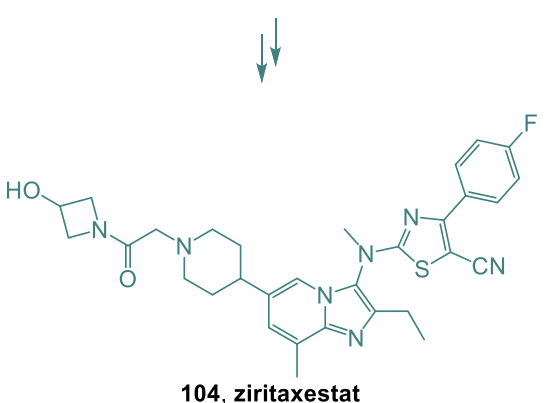

104, ziritaxestat

Scheme 22. Synthesis of an intermediate en route to ziritaxestat. 


\section{Conclusions}

With the advent of emerging cross-coupling technologies such as Suzuki-Miyaura and Buchwald-Hartwig reactions, pharmaceutical synthesis has become quickly possible. The vast studies performed to understand their mechanisms and reactivity support further development of ligands and catalyst for the couplings of highly complex molecules. Extending the applications of Pd-catalyzed cross coupling from medicinal chemistry to process chemistry has significantly reduced the associated time, cost, and waste in the synthesis of active pharmaceutical ingredients. As highlighted in this review, both cross-coupling reactions are the epitome of drug development, and their utility will only keep growing.

Author Contributions: Conceptualization, B.S.T. methodology, B.S.T., F.-Y.K. and R.R.T.; writing—original draft preparation, B.S.T., F.-Y.K. and R.R.T.; writing - review and editing, B.S.T., F.-Y.K. and R.R.T.; supervision, B.S.T. All authors have read and agreed to the published version of the manuscript.

Funding: This research received no external funding.

Institutional Review Board Statement: Not applicable.

Informed Consent Statement: Not applicable.

Data Availability Statement: Not applicable.

Acknowledgments: Fan-Yi Kong graciously acknowledges the Remote Alternative Independent Summer Experience program for financial support and Nicholas D. Ball for mentorship on this project.

Conflicts of Interest: The authors declare no conflict of interest.

\section{References}

1. Garrett, C.E.; Prasad, K. The Art of Meeting Palladium Specifications in Active Pharmaceutical Ingredients Produced by Pd-Catalyzed Reactions. Adv. Synth. Catal. 2004, 346, 889-900. [CrossRef]

2. Phillips, S.; Holdsworth, D.; Kauppinen, P.; Mac Namara, C. Palladium Impurity Removal from Active Pharmaceutical Ingredient Process Streams. Johns. Matthey Technol. Rev. 2016, 60, 277-286. [CrossRef]

3. Thakore, R.R.; Iyer, K.S.; Lipshutz, B.H. Sustainable Routes to Amines in Recyclable Water Using Ppm Pd Catalysis. Curr. Opin. Green Sustain. Chem. 2021, 31, 100493. [CrossRef]

4. Takale, B.S.; Thakore, R.R.; Handa, S.; Gallou, F.; Reilly, J.; Lipshutz, B.H. A New, Substituted Palladacycle for Ppm Level Pd-Catalyzed Suzuki-Miyaura Cross Couplings in Water. Chem. Sci. 2019, 10, 8825-8831. [CrossRef] [PubMed]

5. Phillips, S.; Kauppinen, P. Final Analysis: The Use of Metal Scavengers for Recovery of Palladium Catalyst from Solution. Platin. Met. Rev. 2010, 54, 69-70. [CrossRef]

6. Johansson Seechurn, C.C.C.; Kitching, M.O.; Colacot, T.J.; Snieckus, V. Palladium-Catalyzed Cross-Coupling: A Historical Contextual Perspective to the 2010 Nobel Prize. Angew. Chem. Int. Ed. 2012, 51, 5062-5085. [CrossRef]

7. St-Jean, F.; Remarchuk, T.; Angelaud, R.; Carrera, D.E.; Beaudry, D.; Malhotra, S.; McClory, A.; Kumar, A.; Ohlenbusch, G.; Schuster, A.M.; et al. Manufacture of the PI3K $\beta$-Sparing Inhibitor Taselisib. Part 2: Development of a Highly Efficient and Regioselective Late-Stage Process. Org. Process Res. Dev. 2019, 23, 783-793. [CrossRef]

8. Ndubaku, C.O.; Heffron, T.P.; Staben, S.T.; Baumgardner, M.; Blaquiere, N.; Bradley, E.; Bull, R.; Do, S.; Dotson, J.; Dudley, D.; et al. Discovery of 2-\{3-[2-(1-Isopropyl-3-Methyl-1H-1,2-4-Triazol-5-Yl)-5,6-Dihydrobenzo[f]Imidazo[1,2-d][1,4]Oxazepin-9-Y1]1H-Pyrazol-1-Yl\}-2-Methylpropanamide (GDC-0032): A $\beta$-Sparing Phosphoinositide 3-Kinase Inhibitor with High Unbound Exposure and Robust in Vivo Antitumor Activity. J. Med. Chem. 2013, 56, 4597-4610. [CrossRef] [PubMed]

9. Biscoe, M.R.; Fors, B.P.; Buchwald, S.L. A New Class of Easily Activated Palladium Precatalysts for Facile C-N Cross-Coupling Reactions and the Low Temperature Oxidative Addition of Aryl Chlorides. J. Am. Chem. Soc. 2011, 133, 16707. [CrossRef]

10. Akin, A.; Barilla, M.T.; Brandt, T.A.; Brennan, J.; Henegar, K.E.; Hoagland, S.; Kumar, R.; Magano, J.; McInturff, E.L.; Nematalla, A.; et al. Overcoming the Challenges of Making a Single Enantiomer N-1 Substituted Tetrazole Prodrug Using a Tin-Mediated Alkylation and Enzymatic Resolution. Org. Process Res. Dev. 2019, 23, 1167-1177. [CrossRef]

11. McClure, K.F.; Piotrowski, D.W.; Petersen, D.; Wei, L.; Xiao, J.; Londregan, A.T.; Kamlet, A.S.; Dechert-Schmitt, A.-M.; Raymer, B.; Ruggeri, R.B.; et al. Liver-Targeted Small-Molecule Inhibitors of Proprotein Convertase Subtilisin/Kexin Type 9 Synthesis. Angew. Chem. Int. Ed. 2017, 56, 16218-16222. [CrossRef] [PubMed]

12. Goundry, W.R.F.; Dai, K.; Gonzalez, M.; Legg, D.; O’Kearney-McMullan, A.; Morrison, J.; Stark, A.; Siedlecki, P.; Tomlin, P.; Yang, J. Development and Scale-up of a Route to ATR Inhibitor AZD6738. Org. Process Res. Dev. 2019, 23, 1333-1342. [CrossRef]

13. Foote, K.M.; Nissink, J.W.M.; McGuire, T.; Turner, P.; Guichard, S.; Yates, J.W.T.; Lau, A.; Blades, K.; Heathcote, D.; Odedra, R.; et al. Discovery and Characterization of AZD6738, a Potent Inhibitor of Ataxia Telangiectasia Mutated and Rad3 Related (ATR) Kinase with Application as an Anticancer Agent. J. Med. Chem. 2018, 61, 9889-9907. [CrossRef] [PubMed] 
14. Gontcharov, A.; Magano, J.; Samp, L.; Houck, T.L.; Rose, P.R.; Rane, A.; Coe, J.W.; Kortum, S.W.; Chung, S.; Jones, P.; et al. Development of a Scalable Synthesis for an Inhaled Pan-JAK Inhibitor. Org. Process Res. Dev. 2019, 23, 1990-2000. [CrossRef]

15. Jones, P.; Storer, R.I.; Sabnis, Y.A.; Wakenhut, F.M.; Whitlock, G.A.; England, K.S.; Mukaiyama, T.; Dehnhardt, C.M.; Coe, J.W.; Kortum, S.W.; et al. Design and Synthesis of a Pan-Janus Kinase Inhibitor Clinical Candidate (PF-06263276) Suitable for Inhaled and Topical Delivery for the Treatment of Inflammatory Diseases of the Lungs and Skin. J. Med. Chem. 2017, 60, 767-786. [CrossRef]

16. Baenziger, M.; Pachinger, W.; Stauffer, F.; Zaugg, W. Development of a Robust Synthesis of Dactolisib on a Commercial Manufacturing Scale. Org. Process Res. Dev. 2019, 23, 1908-1917. [CrossRef]

17. Maira, S.-M.; Stauffer, F.; Brueggen, J.; Furet, P.; Schnell, C.; Fritsch, C.; Brachmann, S.; Chène, P.; De Pover, A.; Schoemaker, K.; et al. Identification and Characterization of NVP-BEZ235, a New Orally Available Dual Phosphatidylinositol 3-Kinase/Mammalian Target of Rapamycin Inhibitor with Potent in Vivo Antitumor Activity. Mol. Cancer Ther. 2008, 7, 1851-1863. [CrossRef]

18. Maltais, R.; Poirier, D. Development of a Gram-Scale Synthesis of PBRM, an Irreversible Inhibitor of $17 \beta$-Hydroxysteroid Dehydrogenase Type 1. Org. Process Res. Dev. 2019, 23, 2323-2335. [CrossRef]

19. Maltais, R.; Ayan, D.; Trottier, A.; Barbeau, X.; Lagüe, P.; Bouchard, J.-E.; Poirier, D. Discovery of a Non-Estrogenic Irreversible Inhibitor of $17 \beta$-Hydroxysteroid Dehydrogenase Type 1 from 3-Substituted-16 $\beta$-(m-Carbamoylbenzyl)-Estradiol Derivatives. $J$. Med. Chem. 2014, 57, 204-222. [CrossRef]

20. Zhao, M.M.; Zhang, H.; Iimura, S.; Bednarz, M.S.; Kanamarlapudi, R.C.; Yan, J.; Lim, N.-K.; Wu, W. Process Development of Tryptophan Hydroxylase Inhibitor LX1031, a Drug Candidate for the Treatment of Irritable Bowel Syndrome. Org. Process Res. Dev. 2020, 24, 261-273. [CrossRef]

21. Shi, Z.-C.; Devasagayaraj, A.; Gu, K.; Jin, H.; Marinelli, B.; Samala, L.; Scott, S.; Stouch, T.; Tunoori, A.; Wang, Y.; et al Modulation of Peripheral Serotonin Levels by Novel Tryptophan Hydroxylase Inhibitors for the Potential Treatment of Functional Gastrointestinal Disorders. J. Med. Chem. 2008, 51, 3684-3687. [CrossRef]

22. Hardouin, C.; Baillard, S.; Barière, F.; Copin, C.; Craquelin, A.; Janvier, S.; Lemaitre, S.; Le Roux, S.; Russo, O.; Samson, S Multikilogram Synthesis of a Potent Dual Bcl-2/Bcl-x L Antagonist. 1. Manufacture of the Acid Moiety and Development of Some Key Reactions. Org. Process Res. Dev. 2020, 24, 652-669. [CrossRef]

23. Leverson, J.D.; Phillips, D.C.; Mitten, M.J.; Boghaert, E.R.; Diaz, D.; Tahir, S.K.; Belmont, L.D.; Nimmer, P.; Xiao, Y.; Ma, X.M.; et al. Exploiting Selective BCL-2 Family Inhibitors to Dissect Cell Survival Dependencies and Define Improved Strategies for Cancer Therapy. Sci. Transl. Med. 2015, 7, ra40-ra279. [CrossRef] [PubMed]

24. Kallemeyn, J.M.; Engstrom, K.M.; Pelc, M.J.; Lukin, K.A.; Morrill, W.H.; Wei, H.; Towne, T.B.; Henle, J.; Nere, N.K.; Welch, D.S.; et al. Development of a Large-Scale Route to Glecaprevir: Synthesis of the Macrocycle via Intramolecular Etherification. Org. Process Res. Dev. 2020, 24, 1373-1392. [CrossRef]

25. Zeuzem, S.; Foster, G.R.; Wang, S.; Asatryan, A.; Gane, E.; Feld, J.J.; Asselah, T.; Bourlière, M.; Ruane, P.J.; Wedemeyer, H.; et al Glecaprevir-Pibrentasvir for 8 or 12 Weeks in HCV Genotype 1 or 3 Infection. N. Engl. J. Med. 2018, 378, 354-369. [CrossRef] [PubMed]

26. Schäfer, G.; Fleischer, T.; Ahmetovic, M.; Abele, S. Development of a Scalable Route for a Key Thiadiazole Building Block via Sequential Sandmeyer Bromination and Room-Temperature Suzuki-Miyaura Coupling. Org. Process Res. Dev. 2020, 24, 228-234. [CrossRef]

27. Zhang, J.; Zhu, F.; Tian, G.; Jiang, X.; Shen, J. Improved Synthesis of 6-Chloro-5-Methylpyridin-2-Amine: A Key Intermediate for Making Lumacaftor. Org. Process Res. Dev. 2020, 24, 1175-1179. [CrossRef]

28. Bulloch, M.N.; Hanna, C.; Giovane, R. Lumacaftor/Ivacaftor, a Novel Agent for the Treatment of Cystic Fibrosis Patients Who Are Homozygous for the F580del CFTR Mutation. Expert Rev. Clin. Pharmacol. 2017, 10, 1055-1072. [CrossRef]

29. Smith, D.; Krishnananthan, S.; Meanwell, N.A.; Mathur, A.; Li, J. Multigram Synthesis of BMS-929075, an Allosteric, Palm Site Inhibitor of HCV NS5B Replicase, Involving the Synthesis of a Highly Functionalized Benzofuran through a Telescoped Process. Org. Process Res. Dev. 2020, 24, 1157-1163. [CrossRef]

30. Yeung, K.-S.; Beno, B.R.; Parcella, K.; Bender, J.A.; Grant-Young, K.A.; Nickel, A.; Gunaga, P.; Anjanappa, P.; Bora, R.O.; Selvakumar, K.; et al. Discovery of a Hepatitis C Virus NS5B Replicase Palm Site Allosteric Inhibitor (BMS-929075) Advanced to Phase 1 Clinical Studies. J. Med. Chem. 2017, 60, 4369-4385. [CrossRef] [PubMed]

31. Baenziger, M.; Baierl, M.; Devanathan, K.; Eswaran, S.; Fu, P.; Gschwend, B.; Haller, M.; Kasinathan, G.; Kovacic, N.; Langlois, A.; et al. Synthesis Development of the Selective Estrogen Receptor Degrader (SERD) LSZ102 from a Suzuki Coupling to a C-H Activation Strategy. Org. Process Res. Dev. 2020, 24, 1405-1419. [CrossRef]

32. Tria, G.S.; Abrams, T.; Baird, J.; Burks, H.E.; Firestone, B.; Gaither, L.A.; Hamann, L.G.; He, G.; Kirby, C.A.; Kim, S.; et al. Discovery of LSZ102, a Potent, Orally Bioavailable Selective Estrogen Receptor Degrader (SERD) for the Treatment of Estrogen Receptor Positive Breast Cancer. J. Med. Chem. 2018, 61, 2837-2864. [CrossRef]

33. Parmentier, M.; Wagner, M.; Wickendick, R.; Baenziger, M.; Langlois, A.; Gallou, F. A General Kilogram Scale Protocol for Suzuki-Miyaura Cross-Coupling in Water with TPGS-750-M Surfactant. Org. Process Res. Dev. 2020, 24, 1536-1542. [CrossRef]

34. Lipshutz, B.H.; Ghorai, S.; Abela, A.R.; Moser, R.; Nishikata, T.; Duplais, C.; Krasovskiy, A.; Gaston, R.D.; Gadwood, R.C. TPGS-750-M: A Second-Generation Amphiphile for Metal-Catalyzed Cross-Couplings in Water at Room Temperature. J. Org. Chem. 2011, 76, 4379-4391. [CrossRef] [PubMed] 
35. Graham, M.A.; Askey, H.; Campbell, A.D.; Chan, L.; Cooper, K.G.; Cui, Z.; Dalgleish, A.; Dave, D.; Ensor, G.; Galan Espinosa, M.R.; et al. Development and Scale-Up of an Improved Manufacturing Route to the ATR Inhibitor Ceralasertib. Org. Process Res. Dev. 2021, 25, 43-56. [CrossRef]

36. Xie, H.; Liu, H.; Zhang, Y.; Huang, E.; Feng, Y.; Xiang, X.; Fang, Q.; Peng, Z.; Dong, W.; An, D. Development of a Synthesis Process for a Novel HCV NS5A Inhibitor, Emitasvir. Org. Process Res. Dev. 2021, 25, 838-848. [CrossRef]

37. Schlummer, B.; Scholz, U. Palladium-Catalyzed C-N and C-O Coupling-A Practical Guide from an Industrial Vantage Point. Adv. Synth. Catal. 2004, 346, 1599-1626. [CrossRef]

38. Ueber Phenylirungen bei Gegenwart von Kupfer als Katalysator-Goldberg-1906-Berichte der Deutschen Chemischen Gesellschaft-Wiley Online Library. Available online: https:/ / chemistry-europe.onlinelibrary.wiley.com/doi/abs/10.1002/cber. 19060390298 (accessed on 23 October 2021).

39. Ullmann, F. Ueber Eine Neue Bildungsweise von Diphenylaminderivaten. Ber. Dtsch. Chem. Ges. 1903, 36, 2382-2384. [CrossRef]

40. Kosugi, M.; Kameyama, M.; Migita, T. Palladium-Catalyzed Aromatic Amination of Aryl Bromides with n,n-Di-EthylaminoTributyltin. Chem. Lett. 1983, 12, 927-928. [CrossRef]

41. Guram, A.S.; Buchwald, S.L. Palladium-Catalyzed Aromatic Aminations with in Situ Generated Aminostannanes. J. Am. Chem. Soc. 1994, 116, 7901-7902. [CrossRef]

42. Paul, F.; Patt, J.; Hartwig, J.F. Palladium-Catalyzed Formation of Carbon-Nitrogen Bonds. Reaction Intermediates and Catalyst Improvements in the Hetero Cross-Coupling of Aryl Halides and Tin Amides. J. Am. Chem. Soc. 1994, 116, 5969-5970. [CrossRef]

43. Tao, Y.; Keene, N.F.; Wiglesworth, K.E.; Sitter, B.; McWilliams, J.C. Early Process Development of an Irreversible Epidermal Growth Factor Receptor (EGFR) T790 M Inhibitor. Org. Process Res. Dev. 2019, 23, 382-388. [CrossRef]

44. Cheng, H.; Nair, S.K.; Murray, B.W.; Almaden, C.; Bailey, S.; Baxi, S.; Behenna, D.; Cho-Schultz, S.; Dalvie, D.; Dinh, D.M.; et al. Discovery of 1-\{(3R,4R)-3-[(\{5-Chloro-2-[(1-Methyl-1H-Pyrazol-4-Yl)Amino]-7H-Pyrrolo[2,3-d]Pyrimidin-4-Yl\}oxy)Methyl]-4Methoxypyrrolidin-1-Yl\}prop-2-En-1-One (PF-06459988), a Potent, WT Sparing, Irreversible Inhibitor of T790M-Containing EGFR Mutants. J. Med. Chem. 2016, 59, 2005-2024. [CrossRef]

45. Nonoyama, A.; Nakai, Y.; Lee, S.; Suzuki, S.; Ando, T.; Fukuda, N.; Tanaka, H.; Takahashi, K. Process Development of an Efficient and Cost-Effective Telescoping Route to a Key Synthetic Precursor for the Preparation of a Renin Inhibitor. Org. Process Res. Dev. 2019, 23, 499-511. [CrossRef]

46. Carroll, M.P.; Moloney, H.; Gowran, O.; O'Connor, A.; Wilson, E.M.; Murray, M.M.; Pietz, M.A.; Kjell, D.P.; Held, C.B.; Frederick, M.O. Development of an Improved Route for the Synthesis of an Abemaciclib Intermediate. Org. Process Res. Dev. 2019, 23, 2549-2555. [CrossRef]

47. Li, C.; Franklin, L.; Chen, R.; Mack, T.; Humora, M.; Ma, B.; Hopkins, B.T.; Guzowski, J.; Zheng, F.; MacPhee, M.; et al. Process Development and Large-Scale Synthesis of BTK Inhibitor BIIB068. Org. Process Res. Dev. 2020, 24, 1199-1206. [CrossRef]

48. Sirois, L.E.; Lao, D.; Xu, J.; Angelaud, R.; Tso, J.; Scott, B.; Chakravarty, P.; Malhotra, S.; Gosselin, F. Process Development Overcomes a Challenging Pd-Catalyzed C-N Coupling for the Synthesis of RORc Inhibitor GDC-0022. Org. Process Res. Dev. 2020, 24, 567-578. [CrossRef]

49. Lei, H.; Yang, Y.; Li, C.; Jia, F.; Jiang, N.; Gong, P.; Zhai, X. Catalyst-Free Cyclization- and Curtius Rearrangement-Induced Functional Group Transformation: An Improved Synthetic Strategy of First-in-Class ATX Inhibitor Ziritaxestat (GLPG-1690). Org. Process Res. Dev. 2020, 24, 997-1005. [CrossRef]

50. Joncour, A.; Desroy, N.; Housseman, C.; Bock, X.; Bienvenu, N.; Cherel, L.; Labeguere, V.; Peixoto, C.; Annoot, D.; Lepissier, L.; et al. Discovery, Structure-Activity Relationship, and Binding Mode of an Imidazo[1,2-a]Pyridine Series of Autotaxin Inhibitors. J. Med. Chem. 2017, 60, 7371-7392. [CrossRef] 